\title{
Dystroglycan Glycosylation and Its Involvement in Muscular Dystrophy ジストログリカンの糖鎖修飾と筋ジストロフィー
}

\author{
Kanagawa, Motoi \\ Division of Molecular Brain Science, Kobe University Graduate School of Medicine Kobe, Hyogo 650-0017, Japan \\ FAX: +81-78-382-6288, E-mail: kanagawa@med.kobe-u.ac.jp
}

(Received on March 12, 2014, accepted on March 31, 2014)

Key Words: dystroglycan, O-mannosyl glycosylation, muscular dystrophy, fukutin, gene therapy

\begin{abstract}
Dystroglycan is a highly glycosylated peripheral membrane protein that functions as a cell surface receptor for proteins in the extracellular matrices and synapses. $O$-Mannosyl glycosylation is necessary for the ligand-binding activities of dystroglycan and a unique "post-phosphoryl moiety" modified via a phosphodiester linkage on the $O$-mannose likely forms the ligand-binding domain. Several proteins are involved in the process of this modification, the mechanism for which appears highly ordered. In various tissues, dystroglycan plays important physiological roles such as maintenance of muscle cell viability and structural development of the brain. Conversely, abnormal glycosylation causes a group of muscular dystrophy, collectively called "dystroglycanopathy," which is often associated with brain abnormalities including type II lissencephaly and mental retardation. Here, we will be reviewing the structure, modification pathway, and physiological roles of dystroglycan glycosylation as well as their involvement in human diseases.
\end{abstract}

\section{A. Introduction}

Dystroglycan (DG) was originally identified from the skeletal muscle as a component of the dystrophin-glycoprotein complex (DGC) (1). DGC forms a structural linkage between the basement membranes and actin cytoskeletons, which provides physical strength to the skeletal muscle cell membrane. Within the DGC, the DG functions as a central axis by anchoring the dystrophin underneath the cell membrane, and binding to the basement membrane proteins such as laminin outside of the cells (2) (Fig. 1A). DG consists of $\alpha$ and $\beta$ subunits, both of which are expressed from a single mRNA and cleaved into $\alpha \mathrm{DG}$ and $\beta \mathrm{DG}$ during posttranslational modifications (3). $\alpha \mathrm{DG}$ is a highly glycosylated extracellular protein and functions as a ligand-binding subunit for binding to several ligand proteins, which commonly contain laminin Glike (LG) domains. $\beta$ DG is a transmembrane subunit that anchors the $\alpha \mathrm{DG}$ on the cell surface and binds to dystrophin inside the cells. $\beta$ DG also possibly serves as a signaling molecule since it can be phosphorylated, and it interacts with several adaptor proteins (2,
要 約

ジストログリカンは高度な糖鎖修飾をうける膜タンパク 質で、細胞外マトリックスやシナプス分子の細胞表面受容 体として機能する。ジストログリカンがリガンドと結合す るためには、O-マンノース型の糖鎖修飾が必要で、なかで も、O-マンノース上にリン酸ジエステル結合を介して存在 する “ポストリン酸構造”と呼ばれる修飾体が、リガンド結 合に直接関与するドメインと考えられている。最近、ポスト リン酸修飾にかかわる分子がいくつか同定され、精密な機序 によって修飾が制御されていることがわかってきた。ジスト ログリカンは骨格筋の維持や脳の形成など、さまざまな組織 で重要な役割を担っているが、その一方で、ジストログリカ ンの糖鎖異常はジストログリカノパチーと総称される、脳奇 形（II型滑脳症）や精神発達遅滞などの中枢神経障害を伴う 筋ジストロフィーの原因になる。本稿では、ジストログリカ ンの糖鎖構造、修飾機序、糖鎖機能と疾患との関連について 概説する。

\section{A. はじめに}

ジストログリカン（dystroglycan; DG）は、ジストロフィンー 糖タンパク質複合体（Dystrophin-glycoprotein complex; DGC） の成分として、骨格筋から発見されたのがはじめである(1)。 DGCは、基底膜とアクチン骨格を結ぶ構造を形成しており、 この連携によって筋細胞膜の物理的強度が維持されると考え られている。DGC内において、DGはジストロフィンを細胞膜 直下につなぎとめる一方で、細胞外ではラミニンなどの基底 膜分子と結合しており、細胞骨格と基底膜間を結ぶ分子軸と して機能している(2)（図 1A）。DGは $\alpha$ と $\beta$ 二つのサブユニッ トからなるが、両者は単一の mRNAにコードされており、翻 訳後修飾の過程で $\alpha \mathrm{DG}$ と $\beta \mathrm{DG}$ に切断される (3)。 $\alpha \mathrm{DG}$ は糖鎖 が高度に修飾された細胞外サブユニットで、リガンドと結合 する機能を担っている。 $\alpha \mathrm{DG}$ のリガンド分子はいくつか知ら れているが、いずれも共通してラミニン $\mathrm{G}(\mathrm{LG})$ ドメインを持 つ。 $\beta \mathrm{DG}$ は膜貫通型サブユニットで、細胞外では $\alpha \mathrm{DG}$ を細胞 膜表面につなぎとめておく一方で、細胞内ではジストロフィン 


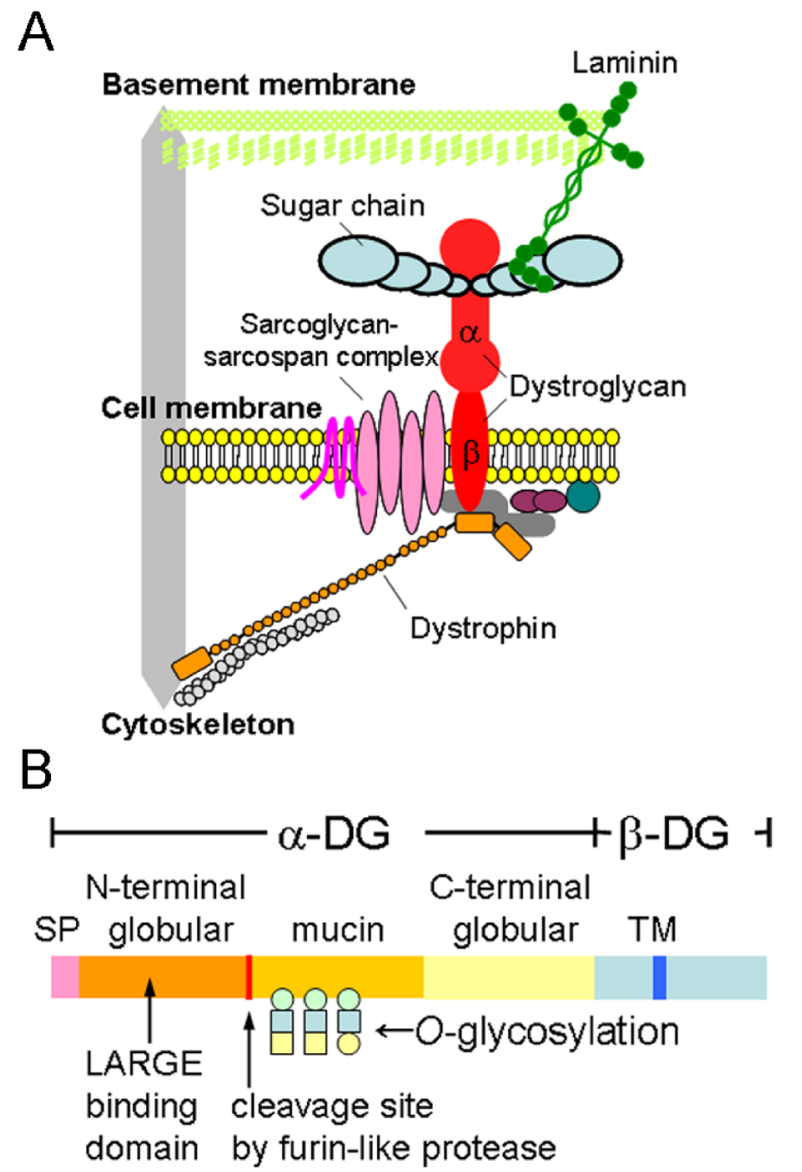

4). $\alpha \mathrm{DG}$ consists of three domains, two globular domains at the Nand C-termini and a mucin-like domain between them (Fig. 1B). The mucin-like domain contains more than $40 \mathrm{Ser} / \mathrm{Thr}$ residues that form $O$-glycan clusters. The N-terminal globular domain is essential for $O$-glycosylation to proceed in the mucin-like domain; however, the N-terminal domain is cleaved and shed from the $\alpha \mathrm{DG}$ core portion after the completion of glycosylation, and therefore not present in mature $\alpha \mathrm{DG}$ (5).

In 1997, Endo and colleagues discovered a unique $O$-mannosyl glycan on $\alpha \mathrm{DG}(\mathrm{Sia} \alpha 2 \rightarrow 3 \mathrm{Gal} \beta 1 \rightarrow 4 \mathrm{GlcNAc} \beta 1 \rightarrow 2 \mathrm{Man})(6)$, which is the first $O$-mannose ( $O$-Man) type glycan identified in mammals. In 2010, Campbell and colleagues reported the presence of a novel moiety that is modified on $O$-Man via a phosphodiester linkage, and proposed that this moiety forms a ligand-binding domain (7). In the early $2000 \mathrm{~s}$, there were consecutive reports from several groups about the incidence of abnormal $\alpha$ DG glycosylation in congenital and limb-girdle type muscular dystrophies, which included Fukuyama congenital muscular dystrophy (FCMD), Walker-Warburg syndrome (WWS), and muscle-eye-brain (MEB) disease $(8,9)$. The abnormal glycosylation of $\alpha \mathrm{DG}$ corresponds to reduction in ligand-binding activities and is a common characteristic of these disorders, which are therefore collectively termed as
Fig. 1. Schematic representation of the dystrophin-glycoprotein complex and dystroglycan. (A) The dystrophin-glycoprotein complex (DGC). (B) The domain structure of dystroglycan. SP, signal peptide; and TM, transmembrane.

と結合している。 $\beta \mathrm{DG}$ はタンパク質リン酸化をうけることや、 アダプター分子と結合することなどから、シグナル分子とし ての機能を持つことも知られている $(2,4)$ 。 $\alpha \mathrm{DG}$ は $\mathrm{N}$ 末 $\mathrm{C}$ 末 にある二つの球状ドメインと、それらに挟まれるムチン様ドメ インに分けられる (図 1B)。ムチン様ドメインには 40 以上の セリンやスレオニン残基が存在し、 $O$ 型糖鎖のクラスターが形 成されている。 $\mathrm{N}$ 末球状ドメインはムチン様ドメインに生じる $O$ 型糖鎖修飾に不可欠な領域であるが、糖鎖修飾完了後にプ ロセシングされるため、細胞膜上に発現している成熟型 $\alpha \mathrm{DG}$ には存在しない $(5)$ 。

1997 年、遠藤らは $\alpha \mathrm{DG}$ にユニークな $O$-マンノース（OMan）型糖鎖（Sia $\alpha 2 \rightarrow 3 \mathrm{Gal} \beta 1 \rightarrow 4 \mathrm{GlcNAc} \beta 1 \rightarrow 2 \mathrm{Man} ）$ が存在す ることをつきとめた $(6)$ 。この構造は哺乳類で初めて発見さ れた $O-M a n$ 型糖鎖である。2010年、Campbellらは $O-$ Man 上 にリン酸ジエステル結合を介して存在する新規修飾構造が 存在することを報告し、これがリガンド結合に関与すると 提唱した (7)。2000年代前半には、福山型筋ジストロフィー (FCMD)、Walker-Warburg 症候群（WWS）、筋眼脳病（MEB 病）をはじめ、先天型や肢帯型筋ジストロフィー患者におい て $\alpha \mathrm{DG}$ の糖鎖修飾に異常が見られることが連続的に報告さ 
Table 1. Dystroglycanopathy genes and their functions.

\begin{tabular}{ll}
\hline Dystroglycanopathy genes & \multicolumn{1}{c}{ Gene functions } \\
\hline POMT1 & O-Mannosyl transferase (POMT1/2 complex) \\
\hline POMT2 & O-Mannosyl transferase (POMT1/2 complex) \\
\hline$P O M G N T 1$ & Protein $O$-mannose $\beta 1,2$-GlcNAc transferase \\
\hline$F K T N$ & Unknown, involved in post-phosphoryl modification? \\
\hline$F K R P$ & Unknown, involved in post-phosphoryl modification? \\
\hline$L A R G E$ & Synthesis of Xyl-GlcA repeating units \\
\hline$I S P D$ & Unknown \\
\hline$G T D C 2 / P O M G N T 2$ & Protein $O$-mannose $\beta 1,4-G l c N A c$ transferase \\
$D A G 1$ & Dystroglycan, reduced interaction with LARGE \\
$T M E M 5$ & Unknown \\
$B 3 G A L N T 2$ & $\beta 1,3$-GalNAc transferase \\
$S G K 196 / P O M K$ & $O$-Man kinase \\
$B 3 G N T 1$ & $\beta 1,3$-GlcNAc transferase \\
$G M P P B$ & GDP-mannose pyrophosphorylase B \\
$D P M 1$ & Dol-P-Man synthesis \\
$D P M 2$ & Dol-P-Man synthesis \\
$D P M 3$ & Dol-P-Man synthesis \\
$D O L K$ & Dolichol phosphate synthesis \\
\hline
\end{tabular}

“dystroglycanopathy" $(10,11)$. Apart from skeletal muscles, dystroglycanopathy is also associated with abnormalities in the central nervous system and the eyes, which signifies the physiological importance of $\alpha \mathrm{DG}$ glycosylation in various tissues. Currently, more than 15 genes, in which mutations cause abnormal glycosylation of $\alpha \mathrm{DG}$ resulting in human disease, have been identified (Table 1). In this review, I will introduce the recent advances that have contributed to the understanding of $\alpha \mathrm{DG}$, especially its sugar chain structure, modification pathway, physiological roles, and relationship with human diseases.

\section{B. Sugar Chain Structure and Modification Mecha- nism of Dystroglycan}

The currently known $O$-mannosyl glycan structures of $\alpha \mathrm{DG}$ and dystroglycanopathy genes are shown in Fig. 2 and Table 1, respectively. Core M1 and Core M3 were originally identified from the bovine peripheral nerve (6) and HEK293 cells that expressed recombinant $\alpha \mathrm{DG}$ proteins (7), respectively. Core M2 is an unidentified structure to date that presumably exists since $\mathrm{N}$-acetylglucosaminyltransferase IX (GnT-IX) can transfer GlcNAc to $O$ Man (12). The $O$-Man in Core M3 is phosphorylated and a unique moiety is modified through a phosphodiester linkage on the $O$ Man. Since its complete structure has not yet been elucidated, this
れた $(8,9)$ 。 $\alpha \mathrm{DG}$ の糖鎖異常とリガンド結合能の消失が共通 した分子病態であることから、これらの疾患はジストログリ カノパチーと総称される $(10,11)$ 。ジストログリカノパチー は筋病変のみならず、中枢神経障害や眼症状を伴う場合も 多く、 $\alpha \mathrm{DG}$ の糖鎖がさまざまな組織において重要な働きを していることが示唆される。現在では 15 種以上の遺伝子が $\alpha \mathrm{DG}$ 糖鎖修飾や病変に関与することが知られている（表 1 )。 本稿では、 $\alpha \mathrm{DG}$ の糖鎖構造、修飾機序、生理機能、疾患と のかかわりについて最近の知見を概説する。

\section{B．ジストログリカンの糖鎖構造と修飾機序}

現在のところ明らかになっている $\alpha \mathrm{DG} の O-\mathrm{Man}$ 型糖鎖 構造を図 2 に、ジストログリカノパチー原因遺伝子を表 1 に 記す。Core M1 はウシ末梢神経より精製した $\alpha$ DGから (6)、 Core M3 はHEK293 細胞に発現させた組み換え $\alpha$ DGから最初 に発見された (7)。N-Acetylglucosaminyltransferase IX（GnTIX）がO-Manに GlcNAcを転移する活性があるため、Core M2が修飾されている可能性も示唆される (12)。Core M3の $O-M a n$ はリン酸化されており、さらにリン酸ジエステル結合 を介して修飾される構造が存在すると示唆されている。この 修飾構造の詳細は完全には明らかにされていないため、“ポ 


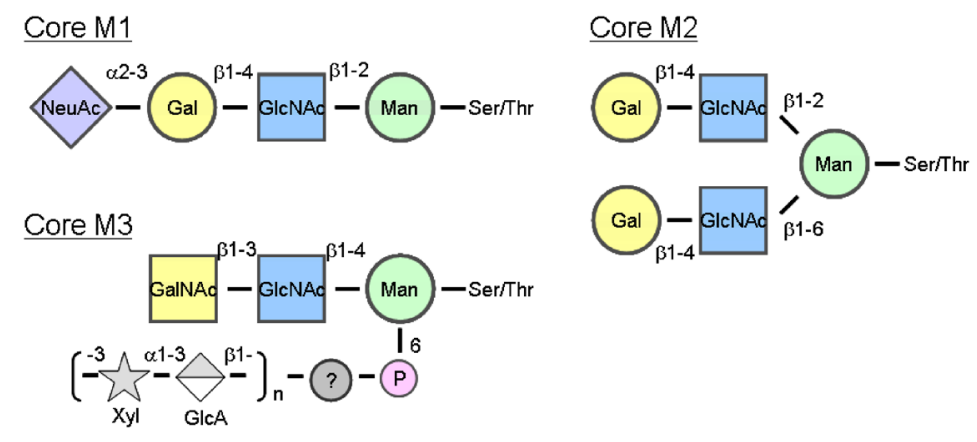

Fig. 2. Sugar chain structures of $\alpha$ DG. Unique $O$-Man glycans of $\alpha \mathrm{DG}$ are illustrated.

structure has been tentatively termed as the "post-phosphoryl moiety" or "post-phosphoryl modification." It is likely that this postphosphoryl moiety contains repeat units consisting of xylose (Xyl) and glucuronic acid (GlcA), which are assembled as a result of the enzymatic activity of LARGE (like-acetylglucosaminyltransferase) (13). The details of the linker structure between the phosphorylated Man (Man-P) and the Xyl-GlcA repeats are unknown to date.

Protein O-mannosyltransferase (POMT) 1 and POMT2 were both identified as the genes responsible for WWS $(14,15)$. POMT1 and POMT2 localize to the endoplasmic reticulum (ER) and form a POMT1/POMT2 heterocomplex (16). This POMT complex catalyzes the transfer of a mannosyl residue from dolicholphosphate mannose (Dol-P-Man) to the Ser and Thr residues of $\alpha \mathrm{DG}$. Protein O-linked mannose $\beta 1,2-N$-acetylglucosaminyltransferase 1 (POMGNT1) was cloned from a cDNA sequence that is homologous to $N$-acetylglucosaminyltransferase I (GnT-I, encoded by $M G A T 1$ ), and was identified as a causative gene for MEB (17). POMGnT1 is a glycosyltransferase that catalyzes the formation of the GlcNAc $\beta 1 \rightarrow 2$ Man linkage by transferring GlcNAc from a UDP-GlcNAc to $O$-Man. It has been reported that the enzymatic removal of NeuAc, Gal, and GlcNAc from Core M1 does not affect the ligand-binding activity of $\alpha \mathrm{DG}$, which suggests that Core M1 may not directly serves as a ligand-binding domain (18). However, in POMGnT1-deficient mice and fibroblasts from MEB patients, the post-phosphoryl modification is partially disrupted, raising the possibility that the structure of Core M1 may influence the biosynthesis of Core M3/post-phosphoryl moiety $(7,19)$.

Glycosyltransferase-like domain containing 2 (GTDC2, POMGNT2), $\beta 1,3-N$-acetylgalactosaminyltransferase 2 (B3GALNT2), and SGK196 (POMK) are newly discovered dystroglycanopathy gene products that are involved in the synthesis of Core M3 (20-23). GTDC2 (alternatively called AGO61) is localized in the ER, and it catalyzes the formation of the GlcNAc $\beta 1 \rightarrow 4$ Man linkage by the transfer of GlcNAc from a UDP-GlcNAc to the $O$-mannosyl peptide derived from $\alpha \mathrm{DG}$. B3GALNT2 is also localized in the ER, and it catalyzes the formation of the
ストリン酸構造”や“ポストリン酸修飾”と呼ばれている。 ポストリン酸構造には、LARGE (like-acetylglucosaminyltransferase）の糖転移酵素活性によって形成されるキシロース $(\mathrm{Xyl})$ とグルクロン酸（GlcA）からなる繰り返し構造が含まれる 可能性が高い(13)。リン酸化ManとXyl-GlcAリピートを結 ぶ構造はまだ明らかにされていない。

Protein O-mannosyltransferase (POMT) 1 とPOMT2 は、い ずれもWWS 原因遺伝子として同定された $(14,15)$ 。両者は 小胞体（ER）に局在し、POMT1/POMT2 複合体を形成した うえで、ドリコールリン酸マンノース（Dol-P-Man）を糖供 与体として、 $\alpha \mathrm{DG}$ のセリン／スレオニン残基への Man転移 反応を触媒する (16)。Protein O-linked mannose $\beta 1,2-N$-acetylglucosaminyltransferase1 (POMGNT1) は、N-acetylglucosaminyltransferase I（GnT-I; 遺伝子名 $M G A T 1 ）$ との相同性をもと にクローニングされ、MEB病の原因遺伝子としても同定さ れた(17)。POMGnT1は、UDP-GlcNAcを糖供与体として、 GlcNAcを $\beta 1,2$ 結合で $O$-Manに転移する酵素である。Core M1 から酵素的にNeuAc、Gal、GlcNAcを除去しても $\alpha \mathrm{DG}$ の リガンド結合能が維持されているとの報告があり、Core M1 はリガンド結合部位として機能していない可能性も報告され ている(18)。一方、POMGnT1-欠損マウスやMEB病患者由 来の細胞では、Core M1のみならず、ポストリン酸修飾も部 分的に不全となるため、Core M1 がCoreM3／ポストリン酸 修飾を調節している可能性が考えられる $(7,19) 。$

Glycosyltransferase-like domain containing 2 (GTDC2, POMGNT2)、 $\beta 1,3-N$-acetylgalactosaminyltransferase 2 (B3GALNT2)、SGK196（POMK）は、比較的新しく同定さ れたジストログリカノパチー原因遺伝子産物で、Core M3 の生合成に関与する(20-23)。GTDC2（AGO61 とも呼ばれ る）はUDP-GlcNAcを糖供与体として O-ManにGlcNAcを $\beta 1 \rightarrow 4$ 結合で、B3GALNT2 はUDP-GalNAcを糖供与体とし て GlcNAc $\beta 1 \rightarrow 4 \mathrm{Man}$ の GlcNAc 残 基に GalNAc を $\beta 1 \rightarrow 3$ 結 合 で転移させる酵素で、いずれも ERに局在することが示唆さ 
GalNAc $\beta 1 \rightarrow 3$ GlcNAc linkage by transferring GalNAc from a UDP-GalNAc. SGK196 catalyzes the addition of a phosphate group from ATP to position 6 on the $O$-Man residues in the Core M3 structure. SGK196 cannot phosphorylate an $O$-mannosyl or a GlcNAc $\beta 1 \rightarrow 4$ Man peptide, indicating that the GalNAc $\beta 1 \rightarrow 3 \mathrm{GlcNAc} \beta 1 \rightarrow 4 \mathrm{Man}$ structure serves as a recognition motif for SGK196. Mutations in any molecule that participates in the synthesis of Core M3 result in dystroglycanopathy. Therefore, highly ordered and sequential actions of the POMT complex, GTDC2, B3GALNT2, and SGK196 are required for subsequent post-phosphoryl modifications. It is not known whether Core M1 and Core M3 can be simultaneously modified on the same $O$-Man residues. In addition, since defects in either Core M1 or Core M3 synthesis result in the loss of ligand-binding activities of $\alpha \mathrm{DG}$, it is necessary to uncover the nature of their relationship in the biosynthetic pathway, and/or in the state of ligand-binding.

LARGE was originally discovered as a gene that was defective in meningiomas (24), and later shown to be causative for spontaneous muscular dystrophy in Large ${ }^{\text {myd }}$ mice (25) and congenital muscular dystrophy 1D (MDC1D) in humans (26). LARGE possesses both xylosyltransferase and glucuronyltransferase activities that produce repeating units of [-3Xyl $\alpha 1 \rightarrow 3 \mathrm{GlcA} \beta 1-]$ using UDP-GlcA and UDP-Xyl as donor substrates (13). Enzymatically synthesized Xyl-GlcA repeats bind to laminin, and their ligandbinding capacity is associated with the length of the repeats (27). Overexpression of LARGE produces hyperglycosylated $\alpha \mathrm{DG}$ that has increased ligand-binding activity, which is likely due to the formation of longer and/or more repeating units. Taken together, it appears that the repeating Xyl-GlcA units function as the ligandbinding epitopes of $\alpha \mathrm{DG}$. For the functional maturation of $\alpha \mathrm{DG}$, the enzymatic activities of LARGE as well as the physical interaction between LARGE and the $\alpha$ DG N-terminal domain are required (5). Thus, the $\mathrm{N}$-terminal domain serves as a recognition motif for LARGE, thereby providing substrate specificity for this unique modification. The N-terminal domain of $\alpha \mathrm{DG}$ is cleaved by furin-like proteases after the glycosylation is completed, and therefore not present in the mature form of $\alpha \mathrm{DG}$. The significance of this cleavage has not yet been understood. Since glycosylation, which is necessary for ligand-binding takes place at a few amino acids downstream of the cleavage site, it possibly provides a stereochemically efficient structure for interaction with the ligands (28). It has been shown that LARGE forms a complex with $\beta 3-N$ acetylglucosaminyltransferase 1 ( $\beta 3 \mathrm{GnT} 1$, encoded by B3GNT1), an enzyme that synthesizes i-antigen (a linear poly- $N$-acetyllactosamine), and this complex is necessary for the functional glycosylation of $\alpha \mathrm{DG}$ (29). Mutations in B3GNT1 were identified in WWS patients (30); however, the roles of $\beta 3 \mathrm{GnT} 1$ or the LARGE/
れている。SGK196はATPを基質にCore M3の Man6位をリ ン酸化する活性を持つ。SGK196は、O-マンノシルペプチド や GlcNAc $\beta 1 \rightarrow 4 \mathrm{Man}$ ペプチドをリン酸化できないため、Gal$\mathrm{NAc} \beta 1 \rightarrow 3 \mathrm{GlcNAc} \beta 1 \rightarrow 4 \mathrm{Man}$ 構造がSGK196の認識モチーフに なっていると考えられる。Core M3 形成に関与するいずれの 遺伝子に変異が生じてもジストログリカノパチーとなるた め、POMT 複合体、GTDC2、B3GALNT2、SGK196が順序だっ て酵素活性を発揮することが、ポストリン酸修飾に必要で ある、という秩序だった機序が成立している。一方で、Core M1、Core M3いずれの異常によっても $\alpha \mathrm{DG}$ のリガンド結合 能が消失するため、生合成過程やリガンド結合状態における 両者の関係性に興味が持たれる。

$L A R G E$ は䯣膜腫で頻繁に見られる欠失領域に位置する 遺伝子として報告され(24)、後に、自然発症の筋ジストロ フィーマウスである Large $e^{\mathrm{myd}}$ マウスの原因遺伝子 $(25)$ 、次い で、先天性筋ジストロフィー（MDC）1D型の原因遺伝子で あることが明らかになった (26)。LARGEはキシロース転移 酵素活性とグルクロン酸転移酵素活性をもち、UDP-Xyl と UDP-GlcA を糖供与体として $[-3 \mathrm{Xyl} \alpha 1 \rightarrow 3 \mathrm{GlcA} \beta 1-]$ の繰り返 し構造を生成する (13)。試験管内で合成したXyl-GlcA 繰り返 し構造には、ラミニン結合活性があること、また、繰り返し 鎖長とリガンド結合量が相関することも示されている $(27)$ 。 LARGE を過剩発現させると $\alpha \mathrm{DG}$ の糖鎖修飾が高度に進行し、 リガンド結合活性も増強するが、これは繰り返し鎖長や修飾 部位が増加するためであろう。以上より、Xyl-GlcA 繰り返し 構造は $\alpha \mathrm{DG}$ のリガンド結合部位として機能していると考えら れる。LARGE酵素活性に加えて、LARGE と $\alpha \mathrm{DG}$ の 末球状 領域との夕ンパク質相互作用もまた $\alpha \mathrm{DG}$ の機能的発現に必要 である(5)。 $\alpha \mathrm{DG}$ の末領域がLARGEによって認識されるこ とが、LARGE依存のユニークな翻訳後修飾の特異性に必要と 考えられる。 $\mathrm{N}$ 末領域は、糖鎖修飾完了後、furin型のプロテ アーゼによって切断されるため、成熟した $\alpha \mathrm{DG} に は$ 存在しな い。このプロセシングの意義は明らかになっていないが、リ ガンド結合にかかわる糖鎖修飾部位が切断部位の直後に位置 することから、リガンドと糖鎖の結合をより効率的に行うた めと推察される (28)。LARGEは $\beta 3-N$-acetylglucosaminyltransferase 1 （ $\beta 3 \mathrm{GnT} 1$; 遺伝子名 $B 3 G N T 1 ）$ と結合することも報告 されている (29)。 $\beta 3 \mathrm{GnT1}$ はi抗原（poly- $N$-acetyllactosamine） の合成に関与する糖転移酵素で、 $\beta 3 \mathrm{GnT} 1 / \mathrm{LARGE}$ 複合体形成 が $\alpha \mathrm{DG}$ 糖鎖修飾に必要とされる。B3GNT1 変異がWWS 患者 に見いだされているが(30)、 $\beta 3 \mathrm{GnT} 1$ 活性や $\beta 3 \mathrm{GnT} 1 / \mathrm{LARGE}$ 複合体が、どのように $\alpha \mathrm{DG}$ 糖鎖修飾に関与しているかは明ら かにされていない。 
$\beta 3 \mathrm{GnT} 1$ complex in the functional maturation of $\alpha \mathrm{DG}$ remain unknown.

Fukutin (FKTN) was identified as the gene responsible for FCMD (31), and a homolog for fukutin was later identified based on sequence homology. The gene product of this homolog was called fukutin-related protein (FKRP) (32). Mutations in FKRP were reported in patients with MDC1C and limb-girdle muscular dystrophy type 2I (LGMD2I) $(32,33)$. Both fukutin and FKRP proteins are localized in the Golgi apparatus and are involved in the post-phosphoryl modifications of $\alpha \mathrm{DG}(7,19)$; however, their exact functions remain unknown. A region in the fukutin protein is homologous to bacterial proteins involved in polysaccharide/ phosphorylcholine modifications and a yeast protein involved in the mannosyl phosphorylation of oligosaccharides (34). Another report proposed that fukutin and FKRP belong to the nucleotidyltransferase (NTase) fold protein superfamily (35). These database retrieval studies may provide some hints about the functions of fukutin and FKRP. TMEM5 is a newly discovered dystroglycanopathy gene that encodes the transmembrane protein 5 (22, 36). TMEM5 protein contains the exostosin-family domain found in EXT1, a glycosyltransferase required for the biosynthesis of heparan sulfate. Even though the exact function of TMEM5 is unknown, it is believed to be a glycosyltransferase. The isoprenoid synthase domain-containing protein (ISPD) belongs to the family of 4-diphosphocytidyl-2C-methyl-D-erythritol (CDP-ME) synthase, and mutations in the ISPD gene were found in WWS patients (37, 38). IspD contributes to the synthesis of isoprenoid precursors in the methylerythritol phosphate (MEP) pathway in Escherichia coli; however, it is postulated that the MEP pathway is absent in mammals. Therefore, specific roles of ISPD especially in relation to $\alpha \mathrm{DG}$ glycosylation are still unknown in humans. It has been proposed that the function of ISPD is crucial for the efficient POMTdependent $O$-mannosylation or synthesis of a novel nucleotide sugar that is required for $\alpha \mathrm{DG}$ glycosylation.

Dolichol-phosphate mannose (Dol-P-Man) acts as a mannose donor in reactions that include $\mathrm{N}$-glycosylation, $\mathrm{O}$-mannosylation, and glycophosphatidylinositol (GPI) anchor biosynthesis in the ER lumen. The synthesis of Dol-P-Man from GDP-Man and dolichol phosphate is catalyzed by the DPM complex, which consists of the catalytic component DPM1 and the ER-localized transmembrane proteins, DPM2 and DPM3. Mutations in DPM1, DPM2, or DPM3 have been identified in patients that show dystroglycanopathy with a type I congenital disorder of glycosylation (CDG) (39-41). CDG is a heterogeneous group of rare genetic disorders that were originally defined as defects in the $N$-glycosylation process, and now reclassified to include $O$-linked and lipid glycosylation defects. In addition, mutations in the gene for dolichol kinase (DOLK), フクチン（fukutin; FKTN） はFCMD原因遺伝子として同 定された $(31)$ 。その後、フクチンと相同性のある分子として fukutin-related protein (FKRP) がクローニングされ(32)、そ の変異が $\mathrm{MDC} 1 \mathrm{C}$ や肢帯型筋ジストロフィー2Iの原因とな ることが報告された $(32,33)$ 。フクチンと FKRPはゴルジ体 に局在し、 $\alpha \mathrm{DG}$ のポストリン酸修飾に関与することが示唆 されているが $(7,19)$ 、現在のところ、両者の活性について は明らかにされていない。フクチンは、バクテリアの多糖 やコリンリン酸修飾にかかわるタンパク質や、酵母多糖の マンノシルリン酸化にかかわるタンパク質と相同性領域を 含むこと(34)、また、フクチンと FKRPは、nucleotidyltransferase (NTase) foldスーパーファミリーに分類されることが 報告されており (35)、フクチンやFKRP活性同定の手がか りになるかもしれない。最近発見されたジストログリカノ パチー原因遺伝子の TMEM5 は、 exostosin glycosyltransferase 1（EXT1）に見られる exostosinファミリー領域を含む膜貫 通型のタンパク質と予想される $(22,36)$ 。EXT1はへパリン 硫酸の生合成に必要な糖転移酵素であるため、TMEM5も また糖転移酵素と考えられるが、その活性はまだ明らかに されていない。 Isoprenoid synthase domain containing protein (ISPD) は 4-diphosphocitidyl-2C-methyl-D-erythritol (CDP-ME) synthase ファミリーに属し、ISPD遺伝子変異がWWS患者に おいて同定されている $(37,38)$ 。大腸菌 Ispdは、イソプレノ イド前駆体の合成にかかわるメチルエリスリトールリン酸 (methylerythritol phosphate; MEP) 経路にかかわるが、哺乳 類にMEP経路は存在せず、ヒトにおけるISPDの機能、特に $\alpha \mathrm{DG}$ 糖鎖修飾にどのようにかかわっているかは不明である。 ISPD がPOMT 依存の O-マンノシル化に関与しているとの説 や、 $\alpha \mathrm{DG}$ の糖鎖修飾に必要な新規の糖ヌクレオチドの生合 成にかかわるとの推察もある。

ドリコールリン酸マンノース（Dolichol-phosphate mannose; Dol-P-Man）は、小胞体での $N$ 型糖鎖修飾、 $O$ 型糖鎖修 飾、グリコシルホスファチジルイノシトールアンカー (GPI) などの生合成にかかわるマンノシル化の供与体で、DPM 合 成複合体によって、GDP-Manとドリコールリン酸から合成 される。DPM合成複合体は、触媒酵素 DPM1 と、ER局在 型膜タンパクのDPM2 と DPM3 からなる。ジストログリカ ノパチー症状と先天性糖鎖異常症（Congenital disorders of glycosylation; CDG）I型を合併する症例において、DPMI、 DPM2、DPM3の変異が同定されている(39-41)。CDGはN 型糖鎖修飾経路の異常を伴った希少疾患群と定義されていた が、最近では、 $O$ 型糖鎖や糖脂質合成経路の異常も含まれる。 DPM 合成複合体の変異以外にも、ドリコールリン酸生成に 
which is responsible for the formation of dolichol phosphate, were discovered in patients with CDG and dilated cardiomyopathy. The heart tissues in these patients showed abnormal $O$-mannosylation of $\alpha \mathrm{DG}$ (42). Mutations in the GDP-mannose pyrophosphorylase $\mathrm{B}(G M P P B)$ gene were recently reported in dystroglycanopathy patients (43). Presumably, mutations in GMPPB result in a decrease in GDP-Man, and consequently Dol-P-Man levels. Taken together, the defects in the Dol-P-Man synthesis pathway should perturb $O$-mannosylation of $\alpha \mathrm{DG}$. However, it is expected that defects in the Dol-P-Man synthesis would also affect $O$-mannosylation, $N$-glycosylation, and GPI anchor formation of other proteins. In fact, defects in $\mathrm{N}$-glycosylation have been revealed in patients with DPM mutations. On the other hand, it is interestingly to note that in all the originally reported cases of GMPPB mutations, there was no evidence of perturbed $\mathrm{N}$-glycosylation. It is not clear why $O$-mannosylation of $\alpha \mathrm{DG}$ is selectively affected in such cases; however, this finding suggests that there may be some competition and/or preference for a common substrate for the $\mathrm{N}$ - and $\mathrm{O}$ glycosylation pathways. The questions, whether gene mutations in the Dol-P-Man biosynthesis pathway can be attributed to a cause of dystroglycanopathy, remains controversial.

\section{Ligand Proteins of DG}

Several extracellular matrix and synaptic proteins such as laminins (44-47), agrin $(48,49)$, perlecan $(50)$, neurexin (51), pikachurin (52), and Slit (53) are known to be ligands of $\alpha \mathrm{DG}$. All these ligand proteins contain LG domains, which function as binding sites for $\alpha \mathrm{DG}$. Since $O$-mannosylations and post-phosphoryl modifications are required for the ligand-binding activities of $\alpha \mathrm{DG}$, the DG-ligand interactions are dramatically reduced in dystroglycanopathy.

Laminin is a major component of the basement membrane and is composed of three subunits $(\alpha, \beta$, and $\gamma)$ (54). The expression patterns of each isoform of laminin (currently more than 15 different isoforms are known) differ among different tissues and cells. In the skeletal muscle basement membrane, the laminin $\alpha 2$ subunit of the main laminin isoform (laminin-211, composed of $\alpha 2, \beta 1$, and $\gamma 1$ subunits) interacts with the $\alpha \mathrm{DG}$ on the muscle cell surface. Mutations in the coding regions of the laminin $\alpha 2$ chain gene are the causative factors for MDC1A, which substantiates the biological importance of laminin-DG interactions (55). Agrin is a heparan sulfate proteoglycan and agrin-DG interactions play important roles in the structural maintenance and stabilization of neuromuscular junctions (56). Perlecan is also a heparin sulfate proteoglycan and one of the major components of basement membranes. The relatively high binding affinities in perlecan-DG interactions possibly indicate certain specific roles of these interactions (45).
関与するドリコールキナーゼ $(D O L K)$ 変異も拡張型心筋症 とCDGを合併した患者から同定されており、患者心筋での $\alpha \mathrm{DG}$ 糖鎖異常が認められている(42)。また、GDP-mannose pyrophosphorylase B 遺伝子 $(G M P P B)$ の変異もジストログ リカノパチー患者から報告されている(43)。GMPPB変異に よって、GDP-Manの合成量が減少し、結果として Dol-P-Man 量も低下すると推察される。つまり、これらの疾患では、 Dol-P-Man 合成経路の異常によって、 $\alpha \mathrm{DG}$ の糖鎖修飾にも影 響が及んだものと考えられる。しかし、Dol-P-Man合成障害 は、 $\alpha \mathrm{DG}$ 以外の $O$-マンノシル化や $N$ 型糖鎖修飾、GPIアン カーの形成などにも影響するはずである。実際、DPM変異 患者は $N$ 型糖鎖修飾異常も併せ持つ。一方で、GMPPB 変異 患者では $N$ 型糖鎖異常を認めないケースもある。このケース のようにDol-P-Man 合成経路の異常が、 $\alpha \mathrm{DG}$ のーマンノシ ル化に選択的に作用する理由は不明だが、O-マンノシル化 経路と $N$ 型糖鎖修飾経路の競合や共通基質の選択性の違いな どが原因かもしれない。Dol-P-Man合成経路に関する遺伝子 変異が、ジストログリカノパチー原因遺伝子と定義できるか については議論の余地が残されている。

\section{DGのリガンド}

$\alpha \mathrm{DG}$ のリガンドとしては、ラミニン (44-47)、アグリン

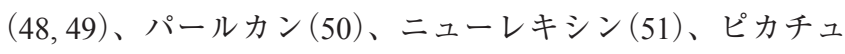
リン (52)、Slit(53)、といった細胞外マトリクス分子やシナ プス分子などが知られている。いずれもラミニン G $(\mathrm{LG})$ ドメインを含む構造を持つが、この LGドメインが $\alpha \mathrm{DG}$ との 結合部位になっている。 $O$-Man型糖鎖修飾とポストリン酸修 飾は $\alpha \mathrm{DG}$ のリガンド結合活性に不可欠なため、ジストログ リカノパチーでは、 $\alpha \mathrm{DG}$ のリガンド結合活性が劇的に低下 している。

ラミニンは基底膜を構成する主要成分の一つで、 $\alpha$ 鎖、 $\beta$ 鎖、 $\gamma$ 鎖の三つのサブユニットからなる $(54)$ 。現在 15 種以 上のアイソフォームが知られているが、それぞれの発現は組 織や細胞によって異なる。骨格筋の基底膜では、ラミニン $211(\alpha 2, \beta 1, \gamma 1)$ が主に発現しており、ラミニン $\alpha 2$ 鎖を介し て筋細胞表面の $\alpha \mathrm{DG}$ と結合している。ラミニン $\alpha 2$ 遺伝子の 変異がMDC1Aの原因になることからも、ラミニンと DG 結 合の重要性がうかがえる(55)。アグリンはヘパラン硫酸プロ テオグリカンで、DGとの結合は神経筋接合部の構造的な維 持や安定性に重要とされている (56)。パールカンもまた基底 膜を構成する主要なへパラン硫酸プロテオグリカンのひとつ である。パールカンはDGに対して比較的高い結合親和性を 示すことから、パールカンと DGとの結合は何らかの特異的 
Neurexins are transmembrane proteins that are expressed in the nervous system. There are two families of neurexins, $\alpha$ - and $\beta$-neurexins, and both families can bind to $\alpha \mathrm{DG}$. Neurexins are cell adhesion molecules, which are mostly located on the presynaptic membranes; whereas, evidence suggests that the synaptic $\alpha \mathrm{DG}$ is expressed on the postsynaptic membranes (57). The significance of the neurexin-DG interactions is still unclear, but it may possibly be involved in synapse formation and/or maintenance. Pikachurin is expressed in the synaptic clefts of the photoreceptor ribbon synapses. The pikachurin-DG interactions play important roles in the maintenance of retinal synapse structures, synaptic signal transmissions, and visual functions $(52,58)$. Slit is a protein widely referred to as a repulsive axon guidance cue and Robo is its known transmembrane receptor. Slit-DG interactions are required for the proper localization of Slit, suggesting a new function for $\alpha \mathrm{DG}$ as an extracellular scaffold for controlling axon guidance (53).

$\alpha \mathrm{DG}$-ligand interactions are calcium-dependent, and the LG domains in the ligand proteins commonly contain $\mathrm{Ca}^{2+}$-coordinating residues $(59,60)$. Some ligand proteins contain several LG domains, which exhibit higher affinity to $\alpha \mathrm{DG}$ when they are adjacent to each other and in tandem, than when present as a single LG domain. This indicates that these tandem LG domains lead to the formation of multiple $\mathrm{Ca}^{2+}$ binding sites and therefore stable interactions with negatively-charged post-phosphoryl moieties of $\alpha$ DG. DG is expressed in almost all tissues and cells, but its glycosylation patterns differ among various tissues (19). It is possible that the variable glycosylation pattern of $\alpha \mathrm{DG}$ leads to ligand selectivity. A recent study has suggested that the length of repeating units of Xly-GlcA is a determinant for the ligand binding capacity (27). In some normal tissues, the post-phosphoryl modifications are either lacking (testis) or less modified (lung) (19). Therefore, it is believed that various parameters including $\alpha \mathrm{DG}$ glycosylation patterns, local concentrations of ligand proteins on the cell surface, and ligand binding affinities are critical for the various physiological functions of $\alpha \mathrm{DG}$-ligand interactions (61).

$\alpha \mathrm{DG}$ is also known as a cellular receptor for arenaviruses such as lymphocytic choriomeningitis virus (LCMV) and Lassa fever virus (LASV), and serves as an entry route for these viruses into host cells (62-64). The $\alpha \mathrm{DG}$-viral interactions also require $O$ mannosyl glycosylation and LARGE-dependent modifications. The viral binding sites partly overlap with those of the matrix ligands. It is believed that the viral envelope glycoprotein, GP1 mediates receptor binding and subsequent cell entry. There are some differences between the LG-domain ligands and the viruses in their binding properties, e.g., binding of the viruses is not calciumdependent whereas LG domain binding is calcium-dependent.
な役割を担っている可能性が考えられる(45)。

ニューレキシンは神経組織に発現する膜貫通型の分 子で、 $\alpha$ と $\beta$ の 2 種類のニューレキシンがあるが、いずれも $\alpha \mathrm{DG}$ と結合する。ニューレキシンと $\alpha \mathrm{DG}$ との結合の生理的 意義は解明されていないが、ニューレキシンがプレシナプス に発現する細胞接着分子であること、そしてDGがポストシ ナプスに発現していることから (57)、シナプスの形成や維持 に関与している可能性がある。ピカチュリンは網膜光受容体 のリボンシナプスに発現しており、DGとの結合は網膜シナ プスの構造、信号伝達、視覚機能の維持に重要とされている $(52,58)$ 。Slitは軸策伸長を反発する効果を持つ軸索誘導因子 で、その膜型受容体としてはRoboが知られている。DGとの 結合はSlitの正常な局在に必要とされることから、DGが軸 索誘導を制御する細胞外の足場として機能している新たな可 能性が考えられる $(53)$ 。

$\alpha \mathrm{DG}$ とリガンドとの結合はカルシウム依存的であり、 リガンド分子の LGドメインには $\mathrm{Ca}^{2+}$ を配位するアミノ酸残 基が保存されている $(59,60)$ 。リガンド分子の多くは複数の LGドメインを持つが、個々のLGドメイン単独よりも、LG ドメインがタンデムになることで、 $\alpha \mathrm{DG} へ の$ 結合親和性が 増加することが多い。LGドメインがタンデムになることで 複数の $\mathrm{Ca}^{2+}$ 結合部位が生まれ、負電荷性のポストリン酸糖 鎖とより効率的に結合できると考えられる。DGはほとんど すべての組織で発現しているが、糖鎖修飾パターンは組織や 細胞によって異なる (19)。このような糖鎖修飾パターンの違 いがリガンド選択性に関与する可能性が考えられる。例え ば、Xyl-GlcAの繰り返し鎖長がリガンド結合量に関係する ことが明らかになった一方で(27)、正常組織であってもポス トリン酸糖鎖が全く修飾されない組織（精巣）や、その量が

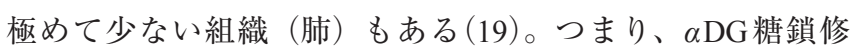
飾パターン、リガンド分子の細胞表面での局在・濃度、DG 親和性や結合量などの要素が、種々のリガンド-DG結合に 多様な生理的意義を与えていると推察される $(61)$ 。

ところで、 $\alpha \mathrm{DG}$ はリンパ球性脈絡髄膜炎ウイルス (LCMV) やラッサ熱ウイルス（LASV）などのアレナウイル スの細胞受容体であり、これらのウイルスの細胞侵入経路に もなる(62-64)。LGドメインを持つリガンド分子の場合と同 様に、O-Man型糖鎖修飾と LARGE依存の修飾がウイルスと の結合に必要である。また、ウイルス結合部位も LGドメイ ン含有リガンド分子の結合部位と部分的に重なっている。ウ イルスエンベロープの糖タンパク質 GP1 が結合にかかわる とされるが、カルシウム非依存的な結合など、LGドメイン 含有リガンド分子との結合様式とは若干の違いがある。 


\section{Human Disorders Caused by Abnormal Glycosyl- ation of $\alpha$-DG (Dystroglycanopathy)}

Muscular dystrophy is a heterogeneous group of genetic disorders that is characterized by the progressive loss of muscle strength and integrity (65). To date, more than 40 genes that are responsible for muscular dystrophy have been identified. In 2001, Hayashi and colleagues reported that the reactivity of the monoclonal antibody IIH6, which is believed to recognize a portion of the $O$-glycan structure of $\alpha \mathrm{DG}$, is dramatically reduced in FCMD patients (8). Subsequently, Campbell and colleagues confirmed that the $\alpha$ DG proteins from FCMD, WWS, and MEB patients are abnormally glycosylated, and have lost their ligand-binding activities (9). Later, mutations in FKRP and LARGE genes were identified in congenital and limb-girdle type muscular dystrophy patients who also exhibited abnormal $\alpha$ DG glycosylation (25, $32,33)$. These discoveries established a new disease entity called muscular dystrophy that is caused by the abnormal glycosylation of $\alpha \mathrm{DG}$, collectively called dystroglycanopathy $(10,11)$. As mentioned before, around 15 dystroglycanopathy genes are known to date, and they are involved in $\alpha \mathrm{DG}$ glycosylation either directly or indirectly. A missense mutation in the DAG1 gene, which encodes DG, was identified in a dystroglycanopathy patient (66). This missense mutation is located within the N-terminal globular domain of $\alpha \mathrm{DG}$ and leads to reduced interactions with LARGE, which likely results in the impaired formation of Xyl-GlcA repeating units.

A number of studies on the genotype-phenotype correlation within large cohorts of dystroglycanopathy patients have revealed that there is a wide clinical spectrum associated with mutations in specific causative genes $(67,68)$. The most severe end of the spectrum is characterized by congenital muscular dystrophy with severe structural abnormalities in the brain and eyes, which usually results in early infantile death. Patients at the mildest end of the spectrum may present in adult life with limb-girdle muscular dystrophy, without the involvement of the brain or eyes. In 2007, Muntoni and colleagues proposed a clinical classification system comprising of seven broad phenotypic categories (67). Later, new Online Mendelian Inheritance in Man (OMIM) entries created a simplified version for classification by combining three broad phenotypic groups and gene defects. There are still some unidentified causative genes for dystroglycanopathy, which could possibly be identified in the near future.

FCMD is the dystroglycanopathy that was first identified, and is the second most common childhood muscular dystrophy in Japan (69). The incidence is around $3 / 100,000$ persons, and one in $\sim 90$ persons is expected to be a heterozygous carrier. FCMD is characterized by congenital muscular dystrophy in combination with abnormalities of the central nervous system (brain malforma-

\section{DG 糖鎖異常症（ジストログリカノパチー）}

筋ジストロフィーは進行性の筋力低下を認める遺伝性 疾患の総称で、現在のところ 40 種以上の原因遺伝子が知ら れている (65)。2001年、林らはFCMD患者において、糖鎖 修飾型 $\alpha$ DG 認識するIIH6 抗体の反応性が著減しているこ とを報告した $(8)$ 。翌年、Campbellらのグループが、FCMD、 WWS、MEB病患者では $\alpha$ DG に糖鎖異常が生じ、リガンド 結合能が消失していることを実証した $(9)$ 。これらの報告に 続いて、 $\alpha \mathrm{DG}$ の糖鎖異常を認める先天型や肢帯型筋ジス卜 ロフィー患者にFKRP変異や $L A R G E$ 変異が見いだされた $(25$, $32,33)$ 。このようにして、 $\alpha \mathrm{DG}$ の糖鎖異常を発症要因とす る筋ジストロフィー（ジストログリカノパチー）という新 しい疾患概念が確立されたのである $(10,11)$ 。現在のところ 15 種類程度の遺伝子がジストログリカノパチー原因遺伝子 として知られており、いずれも $\alpha \mathrm{DG}$ の糖鎖修飾に関与する が、 $\mathrm{DG}$ 遺伝子（DAG1）の変異による症例も報告されてい る(66)。この症例で報告された $D A G 1$ 遺伝子のミスセンス変 異は、 $\alpha \mathrm{DG}$ の 末球状領域内に存在しており、変異によっ てLARGE結合活性が低下し、正常な Xyl-GlcA 繰り返し構造 の修飾が進行しないため発症に至ったと考えられる。

ジストログリカノパチーの遺伝型と表現型の相関に関す る研究から、原因遺伝子が同一であっても臨床像に大きな広 がりがあることが知られている $(67,68)$ 。最重篤型では、重 度の先天性筋ジストロフィーに加え、脳奇形や眼異常を伴 い、乳児期初期で致死に至る。最軽症型では、脳・眼異常 を伴わない成年発症の肢帯型筋ジストロフィーにとどまる。 2007 年、Muntoni らはジストログリカノパチー病型を重篤度 に応じて7種に分類することを提唱し(67)、また、最新の Online Mendelian Inheritance in Man（OMIM）では、簡素化し た 3 種の臨床像と原因遺伝子種の組み合わせによって区分す ることを提唱している。なお、いまだに原因遺伝子が同定さ れていないジストログリカノパチー症例も数多く存在してお り、今後、さらに新しい疾患遺伝子が発見されると予想され る。

FCMD は最初に同定されたジストログリカノパチーで、 本邦の小児期筋ジストロフィーのなかではデュシェンヌ型に 次いで多く見られる (69)。発症頻度は 10 万人あたり 3 人ほど で、日本人の約 90 人に 1 人が保因者と推定される。本症は先 天性筋ジストロフィーに加え、大脳抢よび小脳に多小脳回を 基本とする高度の脳奇形（II 型滑脳症）と重度の精神発達遅 滞を認める (70)。眼症状としては、近視、白内障、視神経低 形成、網膜異形成などが挙げられる。ほとんどの患者は生 
tion characterized by micropolygyria of the cerebrum and cerebellum, type II lissencephaly) and eye (severe myopia, cataract, optic nerve hypoplasia, retinal dysplasia, etc.) (70). Severe mental retardation is observed in all the cases. Most patients are never able to work, and they die by the age of 20 years. The major mutation in FCMD is a SINE-VNTR-Alu (SVA) retrotransoposon insertion in the $3^{\prime}$ noncoding region of the fukutin gene, which accounts for $\sim 87 \%$ of the FCMD chromosome (31). Worldwide, other mutations in fukutin such as frame shift, nonsense, and missense have been also reported. The retrotransposal insertion causes abnormal mRNA splicing, which is induced by a strong acceptor site in SVA and a rare alternative donor site in the exon 10 of fukutin, to produce an aberrantly spliced fukutin protein that lacks 38 amino acids from the C-terminus but contains 129 amino acids derived from the SVA sequence (71). This mutant fukutin protein localizes to the ER. It is believed that this mislocalization and/or lack of a portion of the C-terminal sequence leads to disruption in the activity of fukutin. Several disease-causing point mutations cause misfolding of the fukutin protein resulting in change in its cellular localization from the Golgi apparatus to the ER, which triggers abnormal glycosylation of $\alpha \mathrm{DG}$ (72).

\section{E. Physiological Roles of $\alpha$ DG Glycosylation and Its Relevance to Diseases Pathogenesis}

In dystroglycanopathy, the loss of ligand-binding activity of $\alpha \mathrm{DG}$ due to abnormal glycosylation leads to the disruption of the linkage between the basement membrane and the cytoskeleton. Indeed, an ultrastructural abnormality, in which the basement membrane was detached from the muscle cell membrane, was shown in the skeletal muscle of certain DG-deficient mice as well as a Large-defective Large $e^{\text {myd }}$ dystroglycanopathy mouse (73). These structural abnormalities likely render muscles prone to contractioninduced injuries, eventually leading to the necrosis of muscle cells. Recently, we showed that membrane weakness precedes disease onset, by using myofiber-selective fukutin conditional knockout (MCK-fukutin-cKO) mice, thus demonstrating through proof-of-principle studies that membrane fragility triggers disease manifestation (74). Interestingly, these MCK-fukutin-cKO mice exhibited only mild muscular dystrophy, indicating that membrane fragility is not sufficient for explaining the severe muscle pathology of dystroglycanopathy. When myofibers are damaged, satellite cells (muscle-specific stem cells) are activated for differentiation into muscle precursor cells (MPCs), followed by myoblasts, and eventual fusion into myotubes. Thus, the skeletal muscle can undergo regeneration by means of this process. MPC-selective Myf5fukutin-cKO, which is another fukutin cKO mouse showed severe muscular dystrophy with a reduction in the number of satellite
涯にわたり歩行能力を獲得できず、平均寿命は 20 歳くらい である。FCMD患者で最も多く見られる変異はフクチン遺伝 子 3'非翻訳領域内への SINE-VNTR-Alu（SVA）レトロトラン スポゾン挿入変異で、この変異はFCMD染色体の約 $87 \%$ を 占める $(31)$ 。挿入変異以外にも、フレームシフト、ノンセン ス・ミスセンス変異も国内外から報告されている。SVA 挿入 変異内には強力なスプライシング受容部位が存在しており、 フクチン遺伝子のエクソン 10 内にある潜在的なスプライシ ング供与部位が活性化されることで、異常スプライシングが 生じる (71)。その結果、フクチンのC末端38残基が久損し、 代わりにSVA配列由来の129残基が付加された異常フクチン が産出される。正常フクチンはゴルジ体に局在するが、この 異常フクチンはERに局在する。局在異常やC 末端配列の変 化によって、フクチン機能欠損に至ると考えられる。また、 いくつかの点変異はフクチンのフォールディング異常を引き 起こすが、その結果、フクチンの局在がゴルジ体から ERに 変化し、 $\alpha \mathrm{DG}$ 糖鎖修飾異常が生じると考えられている $(72)$ 。

\section{E. DG糖鎖の生理的役割と病態への関与}

ジストログリカノパチーでは、糖鎖不全によって $\alpha \mathrm{DG}$ のリガンド結合能が低下しているため、基底膜と細胞骨格の 連携が弱化していると考えられる。実際、骨格筋選択的 DG 欠損マウスやジストログリカノパチーモデルである Large変 異L Large $e^{\text {myd }}$ マウスの骨格笳において、基底膜-細胞膜構造の 異常（基底膜の遊離）がみられる(73)。このような構造異 常を認める筋細胞は収縮弛緩に伴う機械的負荷に耐えられず 障害をうけ、最終的には筋壊死に至ると推察される。われわ れは $\alpha \mathrm{DG}$ の糖鎖不全を示す筋線維選択的フクチン conditional KO（MCK-fukutin-cKO） マウスを用いて、細胞膜の脆弱化 が病態に先行して発生していることを明らかにしたが、これ は膜脆弱化が発症の引き金になることの証拠といえる $(74)$ 。 ただし、MCK-fukutin-cKOマウスの病態は軽症で、細胞膜の 脆弱性だけではジストログリカノパチーの重篤な筋病態を説 明できない。骨格筋は損傷すると、衛星細胞と呼ばれる幹細 胞が活性化し、筋前駆細胞 (muscle precursor cell; MPC)、筋 芽細胞、最終的には筋管へと分化することで骨格筋は再生す る。MCK-fukutin-cKOマウスとは異なり、筋前駆細胞選択的 フクチンcKOマウス（Myf5-fukutin-cKO）では重篤な筋病態 を認め、加えて、衛星細胞数、筋前駆細胞の増殖 - 分化活性、 筋再生能が低下していた $(74)$ 。これらの異常は病態の進行に 
cells, proliferation/differentiation activities of MPCs, and muscle regeneration activity (74). These abnormalities become more severe as the disease progresses. These studies revealed that fukutindependent modification of $\alpha \mathrm{DG}$ plays important roles in the maintenance of satellite cell viability and MPC activities, whereas defects in their functions correlate with the severity of the disease. It has been proposed that the absence of $\alpha \mathrm{DG}$ glycosylation during postnatal/juvenile muscle growth and development may have a high impact on muscle degeneration and/or dystrophic pathology in later stages (75). In FCMD and Large ${ }^{\text {myd }}$ mice, the aberrant formation of neuromuscular junctions and the presence of many immature muscle fibers suggest that impaired differentiation signals from these aberrant neuromuscular junctions and maturational delays in muscle fibers underlie the etiology of dystroglycanopathy (76). In addition to muscle membrane fragility, it appears that muscle maturation and regeneration processes are involved in the pathogenesis of dystroglycanopathy.

Abnormal glycosylation of $\alpha \mathrm{DG}$ is also considered as one of the main causes of brain malformation, characterized by polymicrogyria. The surface of the cerebral cortex is covered by the glia limitans/basement membrane complex, which prevents the overmigration of neurons. In FCMD (77) and other dystroglycanopathy models $(9,78)$, there is a breakdown in the basement membrane leading to the protrusion of neurons into the subarachnoid space where the basement membrane breaches are observed. These abnormalities are possibly the underlying causes of cortical dysplasia and type II lissencephaly. $\alpha \mathrm{DG}$ is expressed in radial glia and presumably plays a role in physically connecting the glia limitans to the basement membrane $(78,79)$. During the developmental growth of embryonic brain, abnormally glycosylated $\alpha$-DG may not be able to maintain sufficient physical strength and/or plasticity of the glia limitans-basement membrane complex against an expanding cortical surface area. Interestingly, the neuron-selective DG cKO (NEX-DG-cKO) and Large ${ }^{\text {myd }}$ mice show impairment of long-term potentiation at CA3-CA1 synapses (80). DG is expressed at the postsynaptic apparatus (57) but the precise mechanism mediating the impairment of synaptic plasticity is unknown. Finally, it has been shown that the status of $\alpha \mathrm{DG}$ glycosylation is related to tumor progression $(29,81,82)$. In aggressive prostate and breast carcinoma cell lines, there is a dramatic decrease in lamininbinding glycan levels, suggesting that Xyl-GlcA repeating units may have a tumor-suppressor function.

\section{F. Therapeutic Strategies for Dystroglycanopathy}

In spite of recent progress in identification of disease-causing genes and a deeper understanding of their pathomechanisms, effective therapies for dystroglycanopathy have not yet been estab-
つれて増悪していく。つまり、フクチン依存的に修飾される $\alpha \mathrm{DG}$ の糖鎖は、筋衛星細胞や筋前駆細胞の生存や機能維持 に重要な役割を担っており、その異常が病態重篤度に関与し ていると考えられる。また、出生後や発育期の筋形成・成熟 過程における糖鎖異常が、その後の筋病態に多大な影響を及 ぼす可能性を示唆する報告もある 75 )。さらに、FCMD患者 やL Large $e^{\text {myd }}$ マウスでは、神経筋接合部の形態異常が生じてお り、未成熟な筋線維も多く認められる $(76)$ 。異常な神経筋接 合部由来の筋分化シグナル不全や、筋線維の成熟障害もジス トログリカノパチー病態に関与していると考えられる。この ように、従来から考えられてきた筋細胞膜の脆弱性に加え、 筋形成や再生などのプロセスもまた病態に関与することが明 らかになってきた。

多小脳回を基本とする脳奇形の発生においても、 $\alpha \mathrm{DG}$ 糖鎖異常が病態の中心と考えられる。通常、大脳皮質の表面 はグリア境界膜-基底膜複合体によって覆われており、神経 組織が露出することはない。FCMD患者やジストログリカノ パチーモデルでは、脳表基底膜の連続性の破綻と、破綻箇所 からクモ膜下腔への神経細胞の迷出が観察される $(9,77,78)$ 。 このような異常が皮質形成障害や II 型滑脳症の発生要因と推 察されている。 $\alpha \mathrm{DG}$ は放射状グリアにも発現しており、グ リア境界膜と基底膜の連携に関与していると考えられるが $(78,79)$ 、糖鎖異常型 $\alpha \mathrm{DG}$ では、胎仔脳の成長に伴う脳表拡 張に対して、グリア境界膜-基底膜複合体の物理的強度や可 塑性を維持することができず、基底膜が破綻してしまうの かもしれない。また、神経細胞選択的 DG欠損マウス（NEXDG-cKO）やLarge myd マウスでは、海馬 CA3-CA1 シナプスの 長期増強が低下しているとの報告もある $(80)$ 。DGはポスト シナプスにも発現しているが(57)、シナプス可塑性障害の メカニズムについて今後の展開に興味が持たれる。最後に、 $\alpha \mathrm{DG}$ の糖鎖修飾が腫瘍悪性度に関与する可能性を紹介して おく $(29,81,82)$ 。悪性の前立腺癌細胞や乳癌細胞では、 $\alpha \mathrm{DG}$ のラミニン結合活性が低下していることが知られているが、 これはXyl-GlcA 繰り返し構造が腫瘍抑性作用を持つ可能性 を示唆しているのかもしれない。

\section{F. ジストログリカノパチー治療戦略}

相次ぐ疾患遺伝子の発見や病態の解明が進んできたにも かかわらず、ジストログリカノパチーに有効な治療法は未だ に存在しない。われわれは、治療法の開発を目的に、ジス 
lished. In order to develop therapeutic strategies, we have generated fukutin-deficient mouse models for dystroglycanopathy. Fukutin knockout mice that were generated by the targeted disruption of fukutin were embryonic lethal (83), and chimeric fukutin mice showed a high variability in chimerism amongst individuals and their tissues (84). Although these models proved the biological significance of fukutin-dependent $\alpha$ DG glycosylation, they are not effective for establishing therapeutic strategies. A transgenic knockin (KI) mouse model carrying a retrotransposal insertion in the fukutin gene (fukutin $^{\mathrm{Hp} / \mathrm{Hp}}$, fukutin ${ }^{\mathrm{Hp} /-}$ ) exhibited hypoglycosylation of $\alpha \mathrm{DG}$, but did not show any signs of muscular dystrophy due to the presence of minor levels of intact $\alpha \mathrm{DG}$ with residual lamininbinding activities (85). This study implicates that even a small amount of intact $\alpha \mathrm{DG}$ is sufficient for maintaining skeletal muscle function, and suggests that the treatment of dystroglycanopathy might not require a full recovery of glycosylation.

Considering the pathomechanisms revealed by analyses of the fukutin $\mathrm{cKO}$ and $\mathrm{KI}$ mice, it is clear that any therapeutic strategy must involve (i) prevention of myofiber membrane weakness and/ or (ii) rescue of the substantial loss and dysfunction of MPCs (74). Since frequent cycles of degeneration and regeneration of myofibers accelerate the substantial and/or functional loss of MPCs, it is expected that protection from disease-triggering myofiber degeneration will provide therapeutic effects even in skeletal muscles that contain MPC defects. Therefore, the therapeutic benefits of rescuing fukutin expression that is limited in myofibers were tested. This gene therapy study was conducted by using recombinant adeno-associated virus 9 (AAV9) vectors containing the mouse fukutin cDNA under the control of the MCK promoter, which allowed fukutin expression in differentiated myofibers (74). Results showed that systemic gene delivery into adolescent Myf5-fukutin cKO mice with early-stage muscular dystrophy dramatically ameliorated the dystrophic phenotype and restored muscle function to the same levels, as seen in the wild-type mice. Gene replacement studies using newborn Large ${ }^{\text {myd }}$ and adolescent FKRP-mutant mice have been also reported (86-88). Many genes associated with dystroglycanopathy code for enzymes, and therefore it is expected that even small quantities of exogenously delivered genes that express normal proteins can compensate for the mutant genes. In fact, the therapeutic effects from the fukutin gene transfer were achieved with much lower AAV titers than those used in other types of muscular dystrophy models that had defects in structural proteins. In addition, the therapeutic benefits can attained even after the manifestation of the disease; therefore, we have proposed gene therapy as a feasible treatment for the wide range of dystroglycanopathies. However, the glycosylation status of $\alpha \mathrm{DG}$ varies during myogenesis and muscle regeneration, suggesting that expression patterns
トログリカノパチー疾患モデルとしてさまざまなフクチン 変異マウスを作出してきた。フクチン遺伝子を破壊した全 身性のフクチン欠損マウス（fukutin KO）は胎生致死であり (83)、フクチン欠損キメラマウスは個体・組織ごとにキメラ 率が異なる $(84)$ 。フクチン依存的に修飾される $\alpha \mathrm{DG}$ 糖鎖の 生物学的重要性は証明されたものの、これらのモデルは治療 モデルとしては有効ではなかった。レトロトランスポゾン 挿入変異を持つノックインマウス (フクチン $\mathrm{KI}$; fukutin ${ }^{\mathrm{Hp} / \mathrm{Hp}}$ 、 fukutin $^{\mathrm{Hp} /-}$ ) は $\alpha \mathrm{DG}$ 糖鎖異常を示したものの、筋ジストロ フィー症状は認められなかった $(85)$ 。ノックインマウス骨格 筋では、正常糖鎖型 $\alpha \mathrm{DG}$ が残存しており、ラミニン結合能 も維持されているため、発症に至らなかったと考えられる。 しかし逆に言えば、ジストログリカノパチー治療を考える に、糖鎖異常を完全に解消する必要はなく、部分的にでも回 復できれば治療効果が得られるとの予測も成立する。

フクチン cKOマウスやKIマウスを用いた研究から明ら かになった発症機序を考慮すると、(1)発症の引き金になる筋 細胞膜の脆弱化を抑制すること、(2)筋前駆細胞の量的・質的 な枯渇を抑制すること、が治療戦略として有効と考えられる （74）。ただし、筋細胞膜の脆弱化を抑制できれば、筋壊死／ 再生の頻発のみならず、それに起因する筋前駆細胞の質的・ 量的な枯渇も抑制できるため、仮に筋前駆細胞に異常があっ たとしても治療効果が得られると期待できる。そこでわれ われは、筇線維選択的なフクチン遺伝子発現が治療効果を もたらすか検証するために、筋線維選択的な MCK プロモー ターの下流にフクチン cDNAを配したアデノ随伴ウイルスベ クター（AAV9-MCK-fukutin）を設計した。発症直後の若い Myf5-fukutin-cKOマウスに対して全身性の遺伝子導入を行っ たところ、劇的な病態改善効果が得られ、また、治療によっ て筋力を野生型と同等のレベルにまで改善することに成功し ている(74)。フクチン変異マウス以外にも、新生 Large $e^{\mathrm{myd}}$ マ ウスやFKRP変異マウスへの $\mathrm{AAV}$ 遺伝子治療例も報告され ている(86-88)。ジストログリカノパチー遺伝子の多くは酵 素をコードしているため、少量の遺伝子導入でも十分な治療 効果が得られると予想される。実際、フクチン遺伝子治療の 場合、構造タンパク異常の筋ジストロフィーモデルへの遺伝 子治療に比べ、1/10 1/100 程度のベクター量で治療効果が 得られている。また、発症後の介入であっても治療効果が得 られたことから、遺伝子治療はジストログリカノパチーに有 効な治療法と考えられる。一方で、 $\alpha \mathrm{DG}$ の糖鎖修飾様式は 筋形成や再生の過程で変化するため、 $\alpha \mathrm{DG}$ 糖鎖修飾に関与 する遺伝子（ジストログリカノパチー遺伝子）の発現や遺伝 
and activities of genes involving $\alpha$-DG glycosylation, such as dystroglycanopathy genes are strictly controlled. Therefore, in order to achieve effective therapeutic intervention, it is important to consider the timing of intervention, nature of the targeted cells, and the types of promoters used for driving gene expression.

It has been shown that overexpression of LARGE generates hyperglycosylated $\alpha$-DG, with increased ligand-binding activities in wild-type cells as well as in genetically distinct dystroglycanopathy cells such as from patients that are fukutin-deficient or POMGnT1-deficient (86). These unique characteristics of LARGE led to the development of a novel strategy for treating dystroglycanopathies by enhancing or bypassing the DG-ligand linkage. It has been demonstrated that viral vector-mediated gene transfer of LARGE into POMGnT1-deficient mice improves their motor performance (87). In contrast, a recent report has shown that transgenic overexpression of LARGE in FKRP-mutant mice resulted in a worsening of the muscle pathology (89). Constitutively hyperglycosylated $\alpha \mathrm{DG}$ may have a negative impact in several biological processes. In addition, it has been revealed that LARGE-dependent hyperglycosylation requires $O$-mannosyl phosphorylation and therefore does not always occur in all types of dystroglycanopathies $(38,90)$. Currently, it is not conclusive whether overexpression of LARGE possesses any therapeutic benefits or not.

Finally, I introduce a novel antisense oligonucleotides therapeutic strategy, which is based on the pathogenesis of FCMD (71). As mentioned before, most FCMD patients carry the founder SVA retrotransposal insertion in the 3 '-UTR region of fukutin. This insertion contains a strong splice acceptor site, which induces a rare alternative donor site in the last exon, thus causing abnormal mRNA splicing (exon trapping). The introduction of antisense oligonucleotides that target the splice acceptor, the predicted exonic splicing enhancer, and the intronic splicing enhancer prevented the pathogenic exon trapping by SVA in the cells of FCMD patients as well as model mice. This resulted in the rescue of normal fukutin mRNA expression, protein production, and consequently the restoration of $\alpha \mathrm{DG}$ glycosylation and laminin-binding activity. This treatment strategy can potentially be applied to almost all FCMD patients in Japan, and can therefore be the first radical clinical treatment for dystroglycanopathies.

\section{G. Conclusion}

More than a decade has passed since the discovery of dystroglycanopathy. During this period, there have been advances in identification of the genes responsible for this disorder and in understanding the functions of these genes, the molecular and cellular pathogeneses, as well as the structure and modification pathway of $\alpha$-DG. The issues that remain unresolved include complete
子産物の活性も㛜密に制御されている可能性が高い。遺伝子 治療の場合は、介入時期にくわえ、治療標的細胞や遺伝子発 現プロモーターについても考慮する必要がある。

LARGEを過剩発現させると、正常型 $\alpha \mathrm{DG}$ のならず、 フクチン変異やPOMGnT1変異の細胞に由来する糖鎖異常型 $\alpha \mathrm{DG}$ にも、ラミニン結合性の糖鎖が新たに修飾される $(86)$ 。 このLARGEのユニークな特性に基づき、DG-リガンド結合 の増強／バイパスを狙った、原因遺伝子の種に因らない糖鎖 治療の概念が提唱されている。現在のところ、ウイルスベク ターを用いたLARGE遺伝子導入によって POMGnT1 欠損マ ウスの運動機能が向上したとの報告はあるが(87)、LARGE 過剩発現トランスジェニックマウスとの掛け合わせによって FKRP変異マウスの病態が悪化したとの報告もある $(89)$ 。常 時過剰に増強された糖鎖が負の影響をもたらしている可能性 がある。また、LARGEによる糖鎖増強は、すべてのジスト ログリカノパチーで生じるわけではなく、 $\alpha \mathrm{DG}$ のマンノシ ルリン酸化が必要であることも明らかになってきた $(38,90)$ 。 現在のところ、LARGE特性を応用した治療戦略の有効性に ついては議論の余地が残される。

最後に、FCMD発症機序に基づいた新たなアンチセンス 療法（エクソントラップ阻害療法）を紹介する $(71)$ 。先にも 紹介したように、ほとんどのFCMD患者がレトロトランス ポゾン挿入変異を持つが、この挿入変異のなかには強力なス プライシング受容部位が存在し、タンパク質をコードする最 終エクソン内の潜在的なスプライシング供与部位を活性化さ せることで (エクソントラッピング)、フクチンのスプライ シング異常が発生する。異常スプライシングに関与する配 列（スプライシング受容部位、スプライシングエンハンサー 領域）に対するアンチセンス核酸を患者由来細胞や挿入変異 ノックインマウスに投与したところ、スプライシング異常が 是正され、機能的なフクチンタンパク質が発現し、 $\alpha \mathrm{DG}$ の 糖鎖修飾とラミニン結合活性を正常に戻せることがわかっ た。この治療法は国内におけるほほ全例のFCMD患者を対 象に同一の方法で行えるため、根本的分子標的治療として有 望であり、今後の臨床試験の実現が期待される。

\section{G. おわりに}

ジストログリカノパチーという疾患概念が確立されてか ら 10 年余が経つ。その間、新規疾患遺伝子やその機能、分 子・細胞病態、 $\alpha \mathrm{DG}$ の糖鎖構造や修飾機序が続々と明らか になった。ポストリン酸構造の全容や、未知のジストログリ カノパチー遺伝子の同定などが今後の課題として残されて いるものの、その解明によって、糖鎖生物学や筋ジストロ 
understanding of the post-phosphoryl structures and functions of any unknown dystroglycanopathy genes. Elucidation of these problems should lead to additional breakthroughs in glycobiology and muscular dystrophy research. The effectiveness of antisense and gene replacement therapies raises expectations for future translational research. It is evident that glycobiological and biochemical research has significantly contributed to a deeper understanding of dystroglycanopathy, similar to the manner in which physiological and pathological research has benefitted basic research. Our aim in future research is to study the structures and functions of the sugar chains, for achieving a better understanding and possible cure for dystroglycanopathy.

\section{Acknowledgments}

I would like to thank my former and current mentors, Drs. Kazuya Taniguchi, Kevin P. Campbell, and Tatsushi Toda for their supervision and encouragement. I would also like to thank all the collaborators and members of the laboratories of Dr. Toda and Dr. Campbell for their wonderful support and fruitful discussions.
フィー研究に新たなブレイクスルーがもたらされることは想 像に難くない。さらに、アンチセンス核酸を用いた分子標的 治療や遺伝子治療が有効であることが示され、今後のトラン スレーショナルリサーチへの期待も高まっている。糖鎖生物 学・生化学研究がジストログリカノパチーの解明に多大な貢 献を果たしてきたことは言うまでもないが、一方で、臨床研 究や病理学的研究が重要な生物学的発見にもつながってい る。われわれも、糖鎖構造・機能の解明を基盤にジストログ リカノパチーの克服を目指し、ますます努力を続けていきた いと思う。

\section{謝 辞}

この場をお借りして、懇切なるご指導を賜りました谷口和 弥先生、Kevin P. Campbell先生、戸田達史先生に深謝申し上げ ます。また、長年にわたりご指導いただいております遠藤玉夫 先生、和田芳直先生をはじめ、多くの共同研究者の先生、日々 研究をともに行っている教室員の皆様に深く感謝申し上げます。

\section{References}

1. Ervasti, J. M., Ohlendieck, K., Kahl, S. D., Gaver, M. G., and Campbell, K. P. (1990) Nature 345, 315-319.

2. Barresi, R., and Campbell, K. P. (2006) J. Cell Sci. 119, 199-207.

3. Ibraghimov-Beskrovnaya, O., Ervasti, J. M., Leveille, C. J., Slaughter, C. A., Sernett, S. W., and Campbell, K. P. (1992) Nature 355, 696-702.

4. Moore, C. J., and Winder, S. J. (2012) Neuromuscul. Disord. 22, 959-965.

5. Kanagawa, M., Saito, F., Kunz, S., Yoshida-Moriguchi, T., Barresi, R., Kobayashi, Y. M., Muschler, J., Dumanski, J. P., Michele, D. E., Oldstone, M. B., and Campbell, K. P. (2004) Cell 117, 953-964.

6. Chiba, A., Matsumura, K., Yamada, H., Inazu, T., Shimizu, T., Kusunoki, S., Kanazawa, I., Kobata, A., and Endo, T. (1997) J. Biol. Chem. 272, 2156-2162.

7. Yoshida-Moriguchi, T., Yu, L., Stalnaker, S. H., Davis, S., Kunz, S., Madson, M., Oldstone, M. B., Schachter, H., Wells, L., and Campbell, K. P. (2010) Science 327, 88-92.

8. Hayashi, Y. K., Ogawa, M., Tagawa, K., Noguchi, S., Ishihara, T., Nonaka, I., and Arahata, K. (2001) Neurology 57, $115-121$.

9. Michele, D. E., Barresi, R., Kanagawa, M., Saito, F., Cohn, R. D., Satz, J. S., Dollar, J., Nishino, I., Kelley, R. I., Somer, H., Straub, V., Mathews, K. D., Moore, S. A., and Campbell, K. P. (2002) Nature 418, 417-422.

10. Toda, T., Kobayashi, K., Takeda, S., Sasaki, J., Kurahashi, H., Kano, H., Tachikawa, M., Wang, F., Nagai, Y., Taniguchi, K., Taniguchi, M., Sunada, Y., Terashima, T., Endo, T., and Matsumura, K. (2003) Congenit. Anom. (Kyoto) 43, 97-104.

11. Michele, D. E., and Campbell, K. P. (2003) J. Biol. Chem. 278, 15457-15460.

12. Inamori, K., Endo, T., Gu, J., Matsuo, I., Ito, Y., Fujii, S., Iwasaki, H., Narimatsu, H., Miyoshi, E., Honke, K., and Taniguchi, N. (2004) J. Biol. Chem. 279, 2337-2340

13. Inamori, K., Yoshida-Moriguchi, T., Hara, Y., Anderson, M. E., Yu, L., and Campbell, K. P. (2012) Science 335, $93-96$.

14. Beltrán-Valero de Bernabé, D., Currier, S., Steinbrecher, A., Celli, J., van Beusekom, E., van der Zwaag, B., Kayserili, H., Merlini, L., Chitayat, D., Dobyns, W. B., Cormand, B., Lehesjoki, A. E., Cruces, J., Voit, T., Walsh, C. A., van Bokhoven, H., and Brunner, H. G. (2002) Am. J. Hum. Genet. 71, 1033-1043.

15. van Reeuwijk, J., Janssen, M., van den Elzen, C., Beltran-Valero de Bernabé, D., Sabatelli, P., Merlini, L., Boon, M., Scheffer, H., Brockington, M., Muntoni, F., Huynen, M. A., Verrips, A., Walsh, C. A., Barth, P. G., Brunner, H. G., and van Bokhoven, H. (2005) J. Med. Genet. 42, 907-912.

16. Manya, H., Chiba, A., Yoshida, A., Wang, X., Chiba, Y., Jigami, Y., Margolis, R. U., and Endo, T. (2004) Proc. Natl. Acad. Sci. U.S.A. 101, 500-505.

17. Yoshida, A., Kobayashi, K., Manya, H., Taniguchi, K., Kano, H., Mizuno, M., Inazu, T., Mitsuhashi, H., Takahashi, S., Takeuchi, M., Herrmann, R., Straub, V., Talim, B., Voit, T., Topaloglu, H., Toda, T., and Endo, T. (2001) Dev. Cell 1, 717-724.

18. Combs, A. C., and Ervasti, J. M. (2005) Biochem. J. 390, 303-309.

19. Kuga, A., Kanagawa, M., Sudo, A., Chan, Y. M., Tajiri, M., Manya, H., Kikkawa, Y., Nomizu, M., Kobayashi, K., Endo, T., Lu, Q. L., Wada, Y., and Toda, T. (2012) J. Biol. Chem. 287, 9560-9567.

20. Manzini, M. C., Tambunan, D. E., Hill, R. S., Yu, T. W., Maynard, T. M., Heinzen, E. L., Shianna, K. V., Stevens, C. R., Partlow, J. N., Barry, B. J., Rodriguez, J., Gupta, V. A., Al-Qudah, A. K., Eyaid, W. M., Friedman, J. M., Salih, M. A., Clark, R., Moroni, I., Mora, M., Beggs, A. H., Gabriel, S. B., and Walsh, C. A. (2012) Am. J. Hum. Genet. 91, 541-547.

21. Stevens, E., Carss, K. J., Cirak, S., Foley, A. R., Torelli, S., Willer, T., Tambunan, D. E., Yau, S., Brodd, L., Sewry, C. A., Feng, L., Haliloglu, G., 
Orhan, D., Dobyns, W. B., Enns, G. M., Manning, M., Krause, A., Salih, M. A., Walsh, C. A., Hurles, M., Campbell, K. P., Manzini, M. C., Stemple, D., Lin, Y. Y., and Muntoni, F.; UK10K Consortium. (2013) Am. J. Hum. Genet. 92, 354-365.

22. Jae, L. T., Raaben, M., Riemersma, M., van Beusekom, E., Blomen, V. A., Velds, A., Kerkhoven, R. M., Carette, J. E., Topaloglu, H., Meinecke, P., Wessels, M. W., Lefeber, D. J., Whelan, S. P., van Bokhoven, H., and Brummelkamp, T. R. (2013) Science 340, 479-483.

23. Yoshida-Moriguchi, T., Willer, T., Anderson, M. E., Venzke, D., Whyte, T., Muntoni, F., Lee, H., Nelson, S. F., Yu, L., and Campbell, K. P. (2013) Science 341, 896-899.

24. Peyrard, M., Seroussi, E., Sandberg-Nordqvist, A. C., Xie, Y. G., Han, F. Y., Fransson, I., Collins, J., Dunham, I., Kost-Alimova, M., Imreh, S., and Dumanski, J. P. (1999) Proc. Natl. Acad. Sci. U.S.A. 96, 598-603.

25. Grewal, P. K., Holzfeind, P. J., Bittner, R. E., and Hewitt, J. E. (2001) Nat. Genet. 28, 151-154.

26. Longman, C., Brockington, M., Torelli, S., Jimenez-Mallebrera, C., Kennedy, C., Khalil, N., Feng, L., Saran, R. K., Voit, T., Merlini, L., Sewry, C. A., Brown, S. C., and Muntoni, F. (2003) Hum. Mol. Genet. 12, 2853-2861.

27. Goddeeris, M. M., Wu, B., Venzke, D., Yoshida-Moriguchi, T., Saito, F., Matsumura, K., Moore, S. A., and Campbell, K. P. (2013) Nature 503, $136-140$.

28. Hara, Y., Kanagawa, M., Kunz, S., Yoshida-Moriguchi, T., Satz, J. S., Kobayashi, Y. M., Zhu, Z., Burden, S. J., Oldstone, M. B., and Campbell, K. P. (2011) Proc. Natl. Acad. Sci. U.S.A. 108, 17426-17431.

29. Bao, X., Kobayashi, M., Hatakeyama, S., Angata, K., Gullberg, D., Nakayama, J., Fukuda, M. N., and Fukuda, M. (2009) Proc. Natl. Acad. Sci. U.S.A. 106, 12109-12114.

30. Buysse, K., Riemersma, M., Powell, G., van Reeuwijk, J., Chitayat, D., Roscioli, T., Kamsteeg, E. J., van den Elzen, C., van Beusekom, E., Blaser, S., Babul-Hirji, R., Halliday, W., Wright, G. J., Stemple, D. L., Lin, Y. Y., Lefeber, D. J., and van Bokhoven, H. (2013) Hum. Mol. Genet. 22, $1746-1754$.

31. Kobayashi, K., Nakahori, Y., Miyake, M., Matsumura, K., Kondo-Iida, E., Nomura, Y., Segawa, M., Yoshioka, M., Saito, K., Osawa, M., Hamano, K., Sakakihara, Y., Nonaka, I., Nakagome, Y., Kanazawa, I., Nakamura, Y., Tokunaga, K., and Toda, T. (1998) Nature 394, $388-392$.

32. Brockington, M., Blake, D. J., Prandini, P., Brown, S. C., Torelli, S., Benson, M. A., Ponting, C. P., Estournet, B., Romero, N. B., Mercuri, E., Voit, T., Sewry, C. A., Guicheney, P., and Muntoni, F. (2001) Am. J. Hum. Genet. 69, 1198-1209.

33. Brockington, M., Yuva, Y., Prandini, P., Brown, S. C., Torelli, S., Benson, M. A., Herrmann, R., Anderson, L. V., Bashir, R., Burgunder, J. M., Fallet, S., Romero, N., Fardeau, M., Straub, V., Storey, G., Pollitt, C., Richard, I., Sewry, C. A., Bushby, K., Voit, T., Blake, D. J., and Muntoni, F. (2001) Hum. Mol. Genet. 10, 2851-2859.

34. Aravind, L., and Koonin, E. V. (1999) Curr. Biol. 9, R836-R837.

35. Kuchta, K., Knizewski, L., Wyrwicz, L. S., Rychlewski, L., and Ginalski, K. (2009) Nucleic Acids Res. 37, 7701-7714.

36. Vuillaumier-Barrot, S., Bouchet-Séraphin, C., Chelbi, M., Devisme, L., Quentin, S., Gazal, S., Laquerrière, A., Fallet-Bianco, C., Loget, P., Odent, S., Carles, D., Bazin, A., Aziza, J., Clemenson, A., Guimiot, F., Bonnière, M., Monnot, S., Bole-Feysot, C., Bernard, J. P., Loeuillet, L., Gonzales, M., Socha, K., Grandchamp, B., Attié-Bitach, T., Encha-Razavi, F., and Seta, N. (2012) Am. J. Hum. Genet. 91, $1135-1143$.

37. Roscioli, T., Kamsteeg, E. J., Buysse, K., Maystadt, I., van Reeuwijk, J., van den Elzen, C., van Beusekom, E., Riemersma, M., Pfundt, R., Vissers, L. E., Schraders, M., Altunoglu, U., Buckley, M. F., Brunner, H. G., Grisart, B., Zhou, H., Veltman, J. A., Gilissen, C., Mancini, G. M., Delrée, P., Willemsen, M. A., Ramadža, D. P., Chitayat, D., Bennett, C., Sheridan, E., Peeters, E. A., Tan-Sindhunata, G. M., de Die-Smulders, C. E., Devriendt, K., Kayserili, H., El-Hashash, O. A., Stemple, D. L., Lefeber, D. J., Lin, Y. Y., and van Bokhoven, H. (2012) Nat. Genet. 44, $581-585$.

38. Willer, T., Lee, H., Lommel, M., Yoshida-Moriguchi, T., de Bernabe, D. B., Venzke, D., Cirak, S., Schachter, H., Vajsar, J., Voit, T., Muntoni, F., Loder, A. S., Dobyns, W. B., Winder, T. L., Strahl, S., Mathews, K. D., Nelson, S. F., Moore, S. A., and Campbell, K. P. (2012) Nat. Genet. 44, $575-580$.

39. Yang, A. C., Ng, B. G., Moore, S. A., Rush, J., Waechter, C. J., Raymond, K. M., Willer, T., Campbell, K. P., Freeze, H. H., and Mehta, L. (2013) Mol. Genet. Metab. 110, 345-351.

40. Barone, R., Aiello, C., Race, V., Morava, E., Foulquier, F., Riemersma, M., Passarelli, C., Concolino, D., Carella, M., Santorelli, F., Vleugels, W., Mercuri, E., Garozzo, D., Sturiale, L., Messina, S., Jaeken, J., Fiumara, A., Wevers, R. A., Bertini, E., Matthijs, G., and Lefeber, D. J. (2012) Ann. Neurol. 72, 550-558.

41. Lefeber, D. J., Schönberger, J., Morava, E., Guillard, M., Huyben, K. M., Verrijp, K., Grafakou, O., Evangeliou, A., Preijers, F. W., Manta, P., Yildiz, J., Grünewald, S., Spilioti, M., van den Elzen, C., Klein, D., Hess, D., Ashida, H., Hofsteenge, J., Maeda, Y., van den Heuvel, L., Lammens, M., Lehle, L., and Wevers, R. A. (2009) Am. J. Hum. Genet. 85, 76-86.

42. Lefeber, D. J., de Brouwer, A. P., Morava, E., Riemersma, M., Schuurs-Hoeijmakers, J. H., Absmanner, B., Verrijp, K., van den Akker, W. M., Huijben, K., Steenbergen, G., van Reeuwijk, J., Jozwiak, A., Zucker, N., Lorber, A., Lammens, M., Knopf, C., van Bokhoven, H., Grünewald, S., Lehle, L., Kapusta, L., Mandel, H., and Wevers, R. A. (2011) PLoS Genet. 7, e1002427.

43. Carss, K. J., Stevens, E., Foley, A. R., Cirak, S., Riemersma, M., Torelli, S., Hoischen, A., Willer, T., van Scherpenzeel, M., Moore, S. A., Messina, S., Bertini, E., Bönnemann, C. G., Abdenur, J. E., Grosmann, C. M., Kesari, A., Punetha, J., Quinlivan, R., Waddell, L. B., Young, H. K., Wraige, E., Yau, S., Brodd, L., Feng, L., Sewry, C., Macarthur, D. G., North, K. N., Hoffman, E., Stemple, D. L., Hurles, M. E., van Bokhoven, H., Campbell, K. P., Lefeber, D. J., Lin, Y. Y., and Muntoni, F.; UK10K Consortium. (2013) Am. J. Hum. Genet. 93, $29-41$.

44. Ervasti, J. M., and Campbell, K. P. (1993) J. Cell Biol. 122, 809-823.

45. Talts, J. F., Andac, Z., Göhring, W., Brancaccio, A., and Timpl, R. (1999) EMBO J. 18, 863-870.

46. Ido, H., Harada, K., Futaki, S., Hayashi, Y., Nishiuchi, R., Natsuka, Y., Li, S., Wada, Y., Combs, A. C., Ervasti, J. M., and Sekiguchi, K. (2004) J. Biol. Chem. 279, 10946-10954.

47. Yoon, J. H., Chandrasekharan, K., Xu, R., Glass, M., Singhal, N., and Martin, P. T. (2009) Mol. Cell. Neurosci. 41, 448-463.

48. Gee, S. H., Montanaro, F., Lindenbaum, M. H., and Carbonetto, S. (1994) Cell 77, 675-686.

49. Bowe, M. A., Deyst, K. A., Leszyk, J. D., and Fallon, J. R. (1994) Neuron 12, 1173-1180.

50. Peng, H. B., Ali, A. A., Daggett, D. F., Rauvala, H., Hassell, J. R., and Smalheiser, N. R. (1998) Cell Adhes. Commun. 5, 475-489. 
51. Sugita, S., Saito, F., Tang, J., Satz, J., Campbell, K., and Südhof, T. C. (2001) J. Cell Biol. 154, 435-445.

52. Sato, S., Omori, Y., Katoh, K., Kondo, M., Kanagawa, M., Miyata, K., Funabiki, K., Koyasu, T., Kajimura, N., Miyoshi, T., Sawai, H., Kobayashi, K., Tani, A., Toda, T., Usukura, J., Tano, Y., Fujikado, T., and Furukawa, T. (2008) Nat. Neurosci. 11, 923-931.

53. Wright, K. M., Lyon, K. A., Leung, H., Leahy, D. J., Ma, L., and Ginty, D. D. (2012) Neuron 76, 931-944.

54. Yurchenco, P. D. (2011) Cold Spring Harb. Perspect. Biol. 3, a004911.

55. Gawlik, K. I., and Durbeej, M. (2011) Skelet. Muscle 1, 9.

56. Singhal, N., and Martin, P. T. (2011) Dev. Neurobiol. 71, 982-1005.

57. Zaccaria, M. L., Di Tommaso, F., Brancaccio, A., Paggi, P., and Petrucci, T. C. (2001) Neuroscience 104, 311-324.

58. Kanagawa, M., Omori, Y., Sato, S., Kobayashi, K., Miyagoe-Suzuki, Y., Takeda, S., Endo, T., Furukawa, T., and Toda, T. (2010) J. Biol. Chem. 285, 31208-31216.

59. Hohenester, E., Tisi, D., Talts, J. F., and Timpl, R. (1999) Mol. Cell 4, 783-792.

60. Timpl, R., Tisi, D., Talts, J. F., Andac, Z., Sasaki, T., and Hohenester, E. (2000) Matrix Biol. 19, 309-317.

61. Kanagawa, M., Michele, D. E., Satz, J. S., Barresi, R., Kusano, H., Sasaki, T., Timpl, R., Henry, M. D., and Campbell, K. P. (2005) FEBS Lett. 579, $4792-4796$.

62. Cao, W., Henry, M. D., Borrow, P., Yamada, H., Elder, J. H., Ravkov, E. V., Nichol, S. T., Compans, R. W., Campbell, K. P., and Oldstone, M. B. (1998) Science 282, 2079-2081.

63. Kunz, S., Sevilla, N., McGavern, D. B., Campbell, K. P., and Oldstone, M. B. (2001) J. Cell Biol. 155, 301-310.

64. Oldstone, M. B., and Campbell, K. P. (2011) Virology 411, 170-179.

65. Davies, K. E., and Nowak, K. J. (2006) Nat. Rev. Mol. Cell Biol. 7, 762-773.

66. Hara, Y., Balci-Hayta, B., Yoshida-Moriguchi, T., Kanagawa, M., Beltrán-Valero de Bernabé, D., Gündeşli, H., Willer, T., Satz, J. S., Crawford, R. W., Burden, S. J., Kunz, S., Oldstone, M. B., Accardi, A., Talim, B., Muntoni, F., Topaloğlu, H., Dinçer, P., and Campbell, K. P. (2011) N. Engl. J. Med. 364, 939-946.

67. Godfrey, C., Clement, E., Mein, R., Brockington, M., Smith, J., Talim, B., Straub, V., Robb, S., Quinlivan, R., Feng, L., Jimenez-Mallebrera, C., Mercuri, E., Manzur, A. Y., Kinali, M., Torelli, S., Brown, S. C., Sewry, C. A., Bushby, K., Topaloglu, H., North, K., Abbs, S., and Muntoni, F. (2007) Brain 130, 2725-2735.

68. Godfrey, C., Foley, A. R., Clement, E., and Muntoni, F. (2011) Curr. Opin. Genet. Dev. 21, 278-285.

69. Fukuyama, Y., Osawa, M., and Suzuki, H. (1981) Brain Dev. 3, 1-29.

70. Toda, T., Kobayashi, K., Kondo-Iida, E., Sasaki, J., and Nakamura, Y. (2000) Neuromuscul. Disord. 10, $153-159$.

71. Taniguchi-Ikeda, M., Kobayashi, K., Kanagawa, M., Yu, C. C., Mori, K., Oda, T., Kuga, A., Kurahashi, H., Akman, H. O., DiMauro, S., Kaji, R., Yokota, T., Takeda, S., and Toda, T. (2011) Nature 478, 127-131.

72. Tachikawa, M., Kanagawa, M., Yu, C. C., Kobayashi, K., and Toda, T. (2012) J. Biol. Chem. 287, 8398-8406.

73. Han, R., Kanagawa, M., Yoshida-Moriguchi, T., Rader, E. P., Ng, R. A., Michele, D. E., Muirhead, D. E., Kunz, S., Moore, S. A., Iannaccone, S. T., Miyake, K., McNeil, P. L., Mayer, U., Oldstone, M. B., Faulkner, J. A., and Campbell, K. P. (2009) Proc. Natl. Acad. Sci. U.S.A. 106, 12573-12579.

74. Kanagawa, M., Yu, C. C., Ito, C., Fukada, S., Hozoji-Inada, M., Chiyo, T., Kuga, A., Matsuo, M., Sato, K., Yamaguchi, M., Ito, T., Ohtsuka, Y., Katanosaka, Y., Miyagoe-Suzuki, Y., Naruse, K., Kobayashi, K., Okada, T., Takeda, S., and Toda, T. (2013) Hum. Mol. Genet. 22, $3003-3015$.

75. Beedle, A. M., Turner, A. J., Saito, Y., Lueck, J. D., Foltz, S. J., Fortunato, M. J., Nienaber, P. M., and Campbell, K. P. (2012) J. Clin. Invest. 122, $3330-3342$.

76. Taniguchi, M., Kurahashi, H., Noguchi, S., Fukudome, T., Okinaga, T., Tsukahara, T., Tajima, Y., Ozono, K., Nishino, I., Nonaka, I., and Toda, T. (2006) Hum. Mol. Genet. 15, 1279-1289.

77. Nakano, I., Funahashi, M., Takada, K., and Toda, T. (1996) Acta Neuropathol. 91, 313-321.

78. Moore, S. A., Saito, F., Chen, J., Michele, D. E., Henry, M. D., Messing, A., Cohn, R. D., Ross-Barta, S. E., Westra, S., Williamson, R. A., Hoshi, T., and Campbell, K. P. (2002) Nature 418, 422-425.

79. Myshrall, T. D., Moore, S. A., Ostendorf, A. P., Satz, J. S., Kowalczyk, T., Nguyen, H., Daza, R. A., Lau, C., Campbell, K. P., and Hevner, R. F. (2012) J. Neuropathol. Exp. Neurol. 71, 1047-1063.

80. Satz, J. S., Ostendorf, A. P., Hou, S., Turner, A., Kusano, H., Lee, J. C., Turk, R., Nguyen, H., Ross-Barta, S. E., Westra, S., Hoshi, T., Moore, S. A., and Campbell, K. P. (2010) J. Neurosci. 30, 14560-14572.

81. de Bernabé, D. B., Inamori, K., Yoshida-Moriguchi, T., Weydert, C. J., Harper, H. A., Willer, T., Henry, M. D., and Campbell, K. P. (2009) J. Biol. Chem. 284, 11279-11284.

82. Henry, M. D., Cohen, M. B., and Campbell, K. P. (2001) Hum. Pathol. 32, 791-795.

83. Kurahashi, H., Taniguchi, M., Meno, C., Taniguchi, Y., Takeda, S., Horie, M., Otani, H., and Toda, T. (2005) Neurobiol. Dis. $19,208-217$.

84. Takeda, S., Kondo, M., Sasaki, J., Kurahashi, H., Kano, H., Arai, K., Misaki, K., Fukui, T., Kobayashi, K., Tachikawa, M., Imamura, M., Nakamura, Y., Shimizu, T., Murakami, T., Sunada, Y., Fujikado, T., Matsumura, K., Terashima, T., and Toda, T. (2003) Hum. Mol. Genet. 12, $1449-1459$.

85. Kanagawa, M., Nishimoto, A., Chiyonobu, T., Takeda, S., Miyagoe-Suzuki, Y., Wang, F., Fujikake, N., Taniguchi, M., Lu, Z., Tachikawa, M., Nagai, Y., Tashiro, F., Miyazaki, J., Tajima, Y., Takeda, S., Endo, T., Kobayashi, K., Campbell, K. P., and Toda, T. (2009) Hum. Mol. Genet. 18, 621-631.

86. Barresi, R., Michele, D. E., Kanagawa, M., Harper, H. A., Dovico, S. A., Satz, J. S., Moore, S. A., Zhang, W., Schachter, H., Dumanski, J. P., Cohn, R. D., Nishino, I., and Campbell, K. P. (2004) Nat. Med. 10, 696-703.

87. Yu, M., He, Y., Wang, K., Zhang, P., Zhang, S., and Hu, H. (2013) Hum. Gene Ther. 24, 317-330.

88. Xu, L., Lu, P. J., Wang, C. H., Keramaris, E., Qiao, C., Xiao, B., Blake, D. J., Xiao, X., and Lu, Q. L. (2013) Mol. Ther. 21, $1832-1840$.

89. Whitmore, C., Fernandez-Fuente, M., Booler, H., Parr, C., Kavishwar, M., Ashraf, A., Lacey, E., Kim, J., Terry, R., Ackroyd, M. R., Wells, K. E., Muntoni, F., Wells, D. J., and Brown, S. C. (2014) Hum. Mol. Genet. in press.

90. Yagi, H., Nakagawa, N., Saito, T., Kiyonari, H., Abe, T., Toda, T., Wu, S. W., Khoo, K. H., Oka, S., and Kato, K. (2013) Sci. Rep. 3, 3288. 


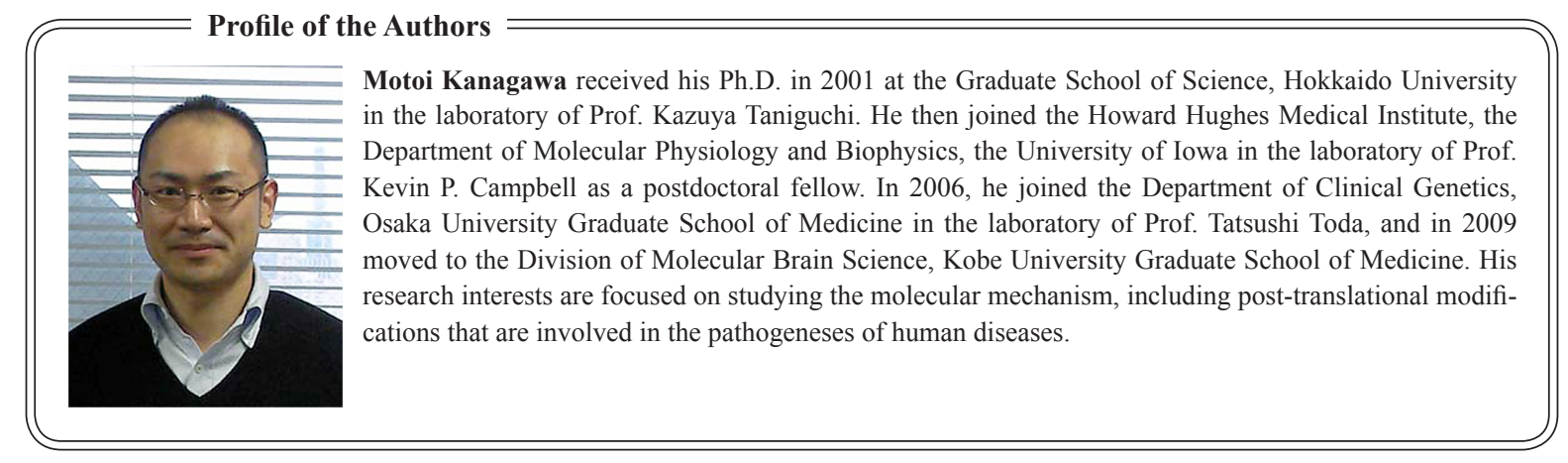

